\title{
Urinary Screening Tests to Detect Excessive Lead Absorption *
}

\author{
R. W. ELLIS \\ From the Nuffield Department of Industrial Health, The Medical School, \\ University of Newcastle upon Tyne
}

\section{PART I: A COMPARISON}

The biological variation encountered in spot urine samples was assessed by collecting six sets of serial urine specimens from five men. The lead, coproporphyrin, and creatinine contents of each specimen were determined and the specific gravity was measured. It is found that as the mean concentration of the metabolite rises so the variability of the individual values increases. The scatter of the concentrations is not significantly different from that found in the rates of excretion. Adjustment of the figures to either a constant specific gravity or creatinine concentration increased the scatter. The effect of the diurnal cycle on the variability is negligible as the spread of the combined results is uniform over the 24-hour period.

The results of spot urine samples must be considered collectively before they can indicate the mean excretion level.

Twenty-four-hour urine samples were obtained from 23 lead-intoxicated men before and throughout their treatment with chelating agents. The initial excretion of lead during intravenous infusion of disodium calcium ethylenediaminetetra-acetate (first $\mathrm{Pb}$ EDTA) and the weight of lead excreted as the complex, before the coproporphyrin excretion falls to a normal level (less than $100 \mu \mathrm{g}$. per day), termed the 'excess' lead, are used as objective measures of the lead absorption. These two indices are linearly related to the pretreatment urinary levels of lead and coproporphyrin, regardless of whether the results are expressed in $\mu \mathrm{g}$. per litre or $\mu \mathrm{g}$. per day. Due to the environment having an effect on the urinary concentrations it is concluded that in general the weight of metabolite excreted in the 24-hour period possibly provides the more reliable guide to the lead absorption of the individual.

The measurement of the lead or coproporphyrin content of urine samples is the usual screening test used throughout industry. When a number of people are employed in the same environment the results can be used in two ways. Hamlin and Weber (1947) and Zielhuis (I96ra) have shown that the average urinary lead or coproporphyrin concentration of a group of men indicates the atmospheric lead concentration to which the group is exposed. Thus by measuring the group average lead and coproporphyrin excretions at regular intervals the lead hazard can be monitored with a reasonable degree of accuracy. The absorption of lead by the individual is assessed by comparing the concentration of each specimen against the maximum urinary concentration (M.U.C.). The M.U.C. is defined as the

\section{Received for publication February 4, 1966.}

\footnotetext{
*This paper is based on part of a thesis submitted for the degree of Master of Science in the University of Newcastle upon Tyne (1965).
}

highest concentration which can be found in the urine without damage to health. Unfortunately there is a considerable divergence of opinion as to the level of the M.U.C., which is in part due to differing definitions of 'health'. Moreover, Buchwald (1964) pointed out that there is some disagreement concerning the collection of the specimen and the manner in which the results of urine analysis should be expressed. It is well known that urine specimens show biological variation, the greatest variability being associated with the results from single voidings.

It appears that although the atmospheric pollution can be satisfactorily monitored by urine analysis the protection afforded to the individual is uncertain.

It is the object of this paper to compare the efficacy of the various factors which are considered when the results of urine analysis are used to assess the degree of lead absorption. For convenience, this work is divided into a consideration of the results of single voidings and of cumulative samples. 


\section{Variability of Single Voidings of Urine}

Most firms rely on the analysis of spot specimens of urine for their screening tests. These show extreme variability and several methods have been suggested to reduce this scatter. It has been proposed that corrections should be made for the time over which the urine is excreted (Barnes, 1939), the volume (Kehoe, Cholak, Hubbard, Bambach, McNary and Story, 1940), a combination of time and volume (Pinto, Elkins, and Ege, 194I), the specific gravity (Levine and Fahy, 1945), and the creatinine concentration (Smith and Kench, 1957). Molyneux (1964) has proposed that the specimen should be collected at a specified time of day.

This investigation was carried out to determine three things: first, the extent of the variation encountered in spot urinary lead and coproporphyrin concentrations and excretion rates; secondly, the value of adjustment for specific gravity and creatinine in reducing the scatter; and finally, the contribution of the diurnal rhythm to the variability.

Experimental Data It is difficult to collect serial urine specimens from active leadworkers. For this reason consecutive specimens were obtained from five hospital in-patients. The men had all had an industrial exposure to lead and showed clinical evidence of excessive absorption. A set of specimens was collected from each man before he was treated with chelating agents. A further set was provided by one of the men while he was convalescing one week after therapy. When the volume was sufficient each sample was analysed for lead (Dick, Ellis, and Steel, I96I), coproporphyrin (Rimington and Sveinsson, 1950), and creatinine content (Varley, 1962). The specific gravity was measured and the time of each voiding was recorded.

The experimental data are given in the Appendix to this paper (p. 276). Each figure in the Tables represents the mean of duplicate or, in the case of lead, triplicate analyses. The 'mean concentration' of each metabolite was determined for each series. This 'mean concentration' was calculated as the total weight of the constituent excreted divided by the total volume of urine collected, i.e., the result of a single cumulative sample (this value will be placed in inverted commas throughout the remainder of the paper). Thus the arithmetical average of the spot values does not necessarily equal the 'mean concentration'.

In Figs. $\mathrm{Ia}$ and $\mathrm{Ib}$ the lowest and highest readings of the lead and coproporphyrin concentrations are plotted against the 'mean concentration'. It is apparent that the spread of the results for each man is increased if his 'mean concentration' is high. The
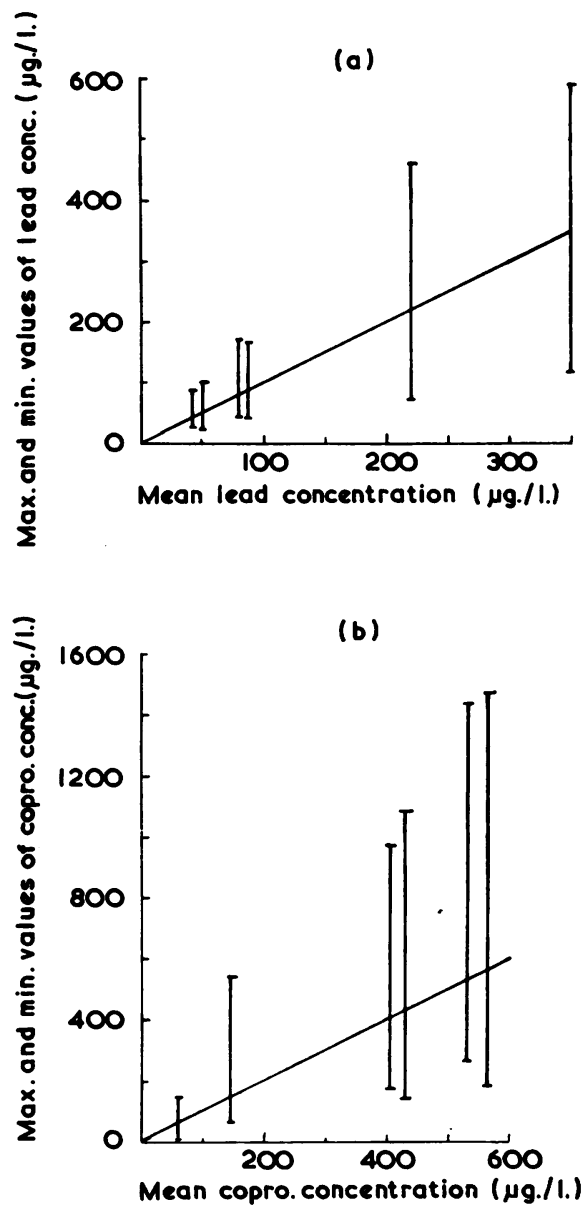

FIG. I. Maximum and minimum values of lead and coproporphyrin ( $\mu \mathrm{g}$./litre) plotted against the 'mean concentration' ( $\mu \mathrm{g}$./litre).

highest readings are about 1o to 20 times the lowest. These findings are in agreement with those of previous workers (Rainsford, 196I; Elkins, 196I; Molyneux, 1964; and others). It is obvious that the variability associated with single voidings of urine is too great for any one figure to give a reliable indication of the excretion level.

To be of practical value, any method for reducing the spread of spot results must either be applicable in all cases or used only within easily defined limits. The original proposal of Levine and Fahy (1945) that all urine concentrations should be reported adjusted to a constant specific gravity of $\mathrm{I} \cdot 024$ has been modified by several investigators. Rainsford (I96I) and Buchwald (1964 and I965) recommended that a standard specific gravity of $\mathrm{r} \cdot 0 \mathrm{r} 6$ was more appropriate for British workpeople. Schoen, 
Young, and Weissman (1959) thought that the specific gravity, as a measure of the renal concentrating ability, is only valid when the specific gravity exceeds $\mathrm{I} \cdot 020$. Price, Miller, and Hayman (1940) showed that the estimation of total urinary solids from the specific gravity is only valid for urines of the same relative composition and that spot specimens are inaccurate due to variations in the solids content. These and other criticisms have led to several investigators suggesting the creatinine concentration as a reference point. However, Bleiler and Schedl (1962), who measured the variability of the creatinine content in 24-hour collections of urine, concluded that the use of creatinine excretion as a reference in interpreting the excretion of other metabolites may be invalid when based on single voidings.

So that the results for the different men and the value of adjustment for specific gravity and creatinine can be compared, each value of the lead and coproporphyrin concentrations was expressed as a proportion of the 'mean concentration' of the series. The lead and coproporphyrin concentrations were adjusted to a constant specific gravity of $1 \cdot 016$ and expressed as a proportion of the 'mean concentration' according to the equation:

$$
\mathrm{Usg}=\frac{\mathrm{U}_{\mathrm{o}} \times \mathrm{G}_{\mathrm{s}}}{\mathrm{G}_{\mathrm{o}}} \times \frac{\mathrm{I00}}{\mathrm{M}}
$$

where Usg is the adjusted proportionate value, $U_{0}$ is the observed concentration ( $\mu \mathrm{g}$./litre), $\mathrm{G}_{\mathrm{g}}$ is (standard specific gravity - I) $\times 1000=16$, $G_{0}$ is (observed specific gravity $\left.-I\right) \times 1000$, and $M$ is the 'mean concentration' ( $\mu$ g./litre). In a similar fashion the lead and coproporphyrin proportions were adjusted to the 'mean creatinine concentration' of the series by the formula:

$$
\mathrm{Ucr}=\frac{\mathrm{U}_{\mathrm{o}} \times \mathrm{Cr}_{\mathrm{s}}}{\mathrm{Cr}_{\mathrm{o}}} \times \frac{100}{\mathrm{M}}
$$

where $U c r$ is the adjusted proportionate value, $U_{0}$ is the observed concentration ( $\mu \mathrm{g}$./litre), $\mathrm{Cr}_{\mathbf{B}}$ is the 'mean creatinine concentration' (g./litre), $\mathbf{C r}_{0}$ is the observed creatinine concentration (g./litre), and $M$ is the 'mean concentration' of the metabolite ( $\mu \mathrm{g}$./litre). The rates of excretion were also expressed as proportions of the average rate of excretion. All proportionate values are included in the Appendix (p. 276).

The individual sets of proportionate values can be pooled to form a combined set. The variability of the individual and combined sets of proportions, measured as the coefficients of variation, are shown in Table $I$.

The opinion that the increase in variability of the specific gravity corrected figures is due to the inclusion of urines of low specific gravity is not substantiated in this investigation. Patients $\mathrm{C}$ and $\mathrm{P}_{2}$ excreted urines ranging from S.G. I.004 to $\mathrm{I} \cdot 016$ and S.G. I.004 to I.020 respectively. Specific gravity adjustment of C's results reduced the lead and coproporphyrin coefficients of variation by about a third, whereas in P2's case adjustment increased both coefficients of variation by half as much again. Furthermore, when specific gravity correction was applied to K's results the coefficient of variation of the lead values was increased but the coefficient of variation of the coproporphyrin figures was reduced. Patient $P$ provided a set of specimens before and after treatment with chelating agents (series $P$ and P2). Before therapy both the lead and coproporphyrin coefficients of variation were reduced by specific gravity correction but after medication adjustment increased both coefficients of variation. It is apparent that there is no simple criterion which indicates when specific gravity adjustment would reduce the variability of the concentrations.

The figures expressed as rates of excretion and as

TABLE I

\begin{tabular}{|c|c|c|c|c|c|c|c|c|c|}
\hline \multirow[t]{3}{*}{ Subject } & \multirow{3}{*}{$\begin{array}{l}\text { No. of } \\
\text { Samples }\end{array}$} & \multicolumn{4}{|l|}{ Lead } & \multicolumn{4}{|c|}{ Coproporphyrin } \\
\hline & & \multirow{2}{*}{$\begin{array}{l}\text { Observed } \\
\text { Result }\end{array}$} & \multicolumn{3}{|c|}{ Adjusted to } & \multirow{2}{*}{$\begin{array}{l}\text { Observed } \\
\text { Result }\end{array}$} & \multicolumn{3}{|c|}{ Adjusted to } \\
\hline & & & $\begin{array}{l}\text { Specific } \\
\text { Gravity }\end{array}$ & Creatinine & Rate & & $\begin{array}{l}\text { Specific } \\
\text { Gravity }\end{array}$ & Creatinine & Rate \\
\hline $\begin{array}{l}\mathbf{C} \\
\mathbf{K} \\
\mathbf{N} \\
\mathbf{P} \\
\mathbf{P} 2 \\
\mathbf{U}\end{array}$ & $\begin{array}{l}13 \\
17 \\
21 \\
17 \\
17 \\
21\end{array}$ & $\begin{array}{l}42 \cdot 8 \\
36 \cdot 0 \\
43 \cdot 7 \\
32 \cdot 5 \\
42 \cdot 5 \\
33 \cdot 2\end{array}$ & $\begin{array}{l}25 \cdot 7 \\
54 \cdot 0 \\
22 \cdot 7 \\
24 \cdot 6 \\
62 \cdot 8 \\
31 \cdot 3\end{array}$ & $\begin{array}{l}37 \cdot 1 \\
59 \cdot 0 \\
66 \cdot 7 \\
46 \cdot 7 \\
51 \cdot 4 \\
35 \cdot 5\end{array}$ & $\begin{array}{l}40 \cdot 0 \\
73 \cdot 5 \\
38 \cdot 0 \\
52 \cdot 5 \\
37 \cdot 4 \\
44 \cdot 7\end{array}$ & $\begin{array}{l}54.5 \\
45 \cdot 9 \\
48 \cdot 8 \\
42 \cdot 5 \\
54.6 \\
58.9\end{array}$ & $\begin{array}{l}32 \cdot 6 \\
31 \cdot 6 \\
32 \cdot 5 \\
28 \cdot 3 \\
76 \cdot 2 \\
50 \cdot 0\end{array}$ & $\begin{array}{l}28 \cdot 7 \\
26 \cdot 8 \\
87 \cdot 2 \\
22 \cdot 4 \\
64 \cdot 1 \\
39 \cdot 7\end{array}$ & $\begin{array}{l}59 \cdot 9 \\
48 \cdot 2 \\
33 \cdot 1 \\
34 \cdot 2 \\
63 \cdot 2 \\
42 \cdot 7\end{array}$ \\
\hline Combined & 106 & $39 \cdot 5$ & $48 \cdot 9$ & $56 \cdot 6$ & $43 \cdot \mathbf{I}$ & $5 I \cdot 9$ & $56 \cdot 1$ & $66 \cdot 6$ & $45 \cdot 7$ \\
\hline
\end{tabular}

COEFFICIENTS OF VARIATION

The coefficients of variation in bold are higher than the observed. 
creatinine corrected proportions show greater variability more frequently than those expressed as specific gravity adjusted values. The coefficients of variation of the combined sets of figures can be compared by Student's ' $t$ ' test of significance, according to the equation:

$$
\text { ' } \mathrm{t} \text { ' }=\frac{\mathrm{CV}_{1}-\mathrm{CV}_{2}}{\sqrt{\frac{\left(\mathrm{CV}_{1}\right)^{2}}{2 \mathrm{~N}_{1}}+\frac{\left(\mathrm{CV}_{2}\right)^{2}}{2 \mathrm{~N}_{2}}}}
$$

where ' $t$ ' is Student's ' $t$ ', $\mathrm{CV}$ is the coefficient of variation, and $N$ is the number of items in the coefficient of variation. It is found that the coefficients of variation of the observed proportions are not significantly different from those of either rates of excretion ( $P>0.4$ and $P>0.2$ for lead and coproporphyrin respectively) or the specific gravity adjusted coproporphyrin figures ( $P>0.4$ ). The coefficients of variation of the observed proportions are significantly lower than either the specific gravity adjusted $(\mathrm{P}<0.05)$ or creatinine corrected $(P<0.001)$ lead values and the creatinine corrected coproporphyrin values $(P<0.02)$.

It appears that correction by any of these methods will reduce the variability of some sets of results. However, the gross increase in variability of the others offsets any advantage in using these techniques as routine control methods.

Turning now to the possibility of a diurnal cycle, it is found that the results for any one man show a rhythmic variation when plotted on a continuous time scale. The urinary lead and coproporphyrin concentrations of each specimen collected from patient $\mathrm{K}$ are shown in Figure 2. It can be seen that the lead values tend to rise from midnight to 8.00 a.m. and to fall to a minimum value at about 8.00 p.m. each day. Similarly, the coproporphyrin values rise between midnight and 8.00 a.m. and fall between noon and 6.00 p.m. However, at any given time, the levels alter considerably from day to day. This indicates that neither the amplitude nor the wavelength of the cycle is constant in the man. In Figs. 3 and 4, where the results of each man are plotted on a 24-hour basis, it is apparent that this day-to-day variation obscures the hourly rhythm. Moreover, when all the results expressed as proportions of their 'mean concentrations' are plotted in the same diagram (Figs. 5 and 6 ) the scatter is equally marked at all times of the day. It seems therefore that, although the diurnal cycle is a component, it contributes only a negligible part of the total variability associated with spot specimens.

These observations are at variance with those of Molyneux (1964). However, the subjects in the present investigation were confined in centrally heated hospital wards and were not allowed any violent exercise. These conditions contrast with those of active lead workers, who are often subjected to an artificial thermal environment, high humidity, and manual labour. In addition, the fluid intake is often restricted to certain periods of the work shift. It seems that these environmental factors, as well as exposure to the hazard, contributed to Molyneux's findings.

It is apparent that the results of a single voiding of urine are in themselves meaningless, regardless of whether or not the specimen is, collected at some specified time, expressed as a rate of excretion or adjusted to either a constant specific gravity or creatinine concentration. Hamlin and Weber (I947) suggested that for the interpretation of spot specimens one has not to be concerned with minutiae but to analyse a sufficient number of collections to arrive

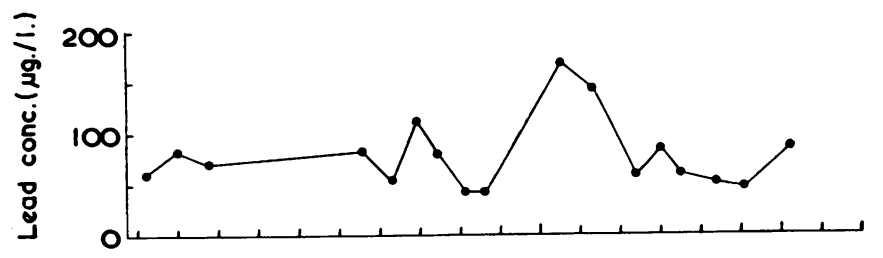

FI3. 2. Diurnal rhythm in urinary metabolite excretion of patient $K$.

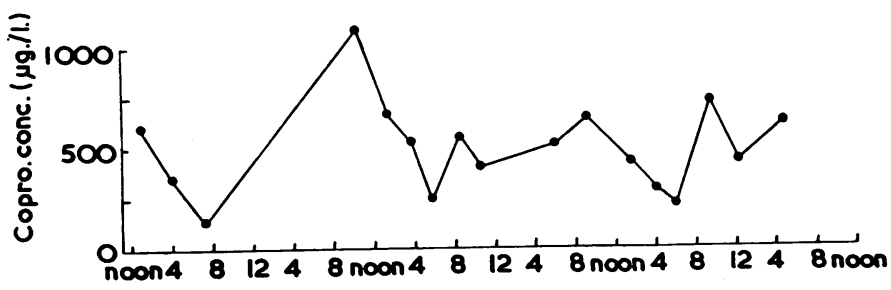




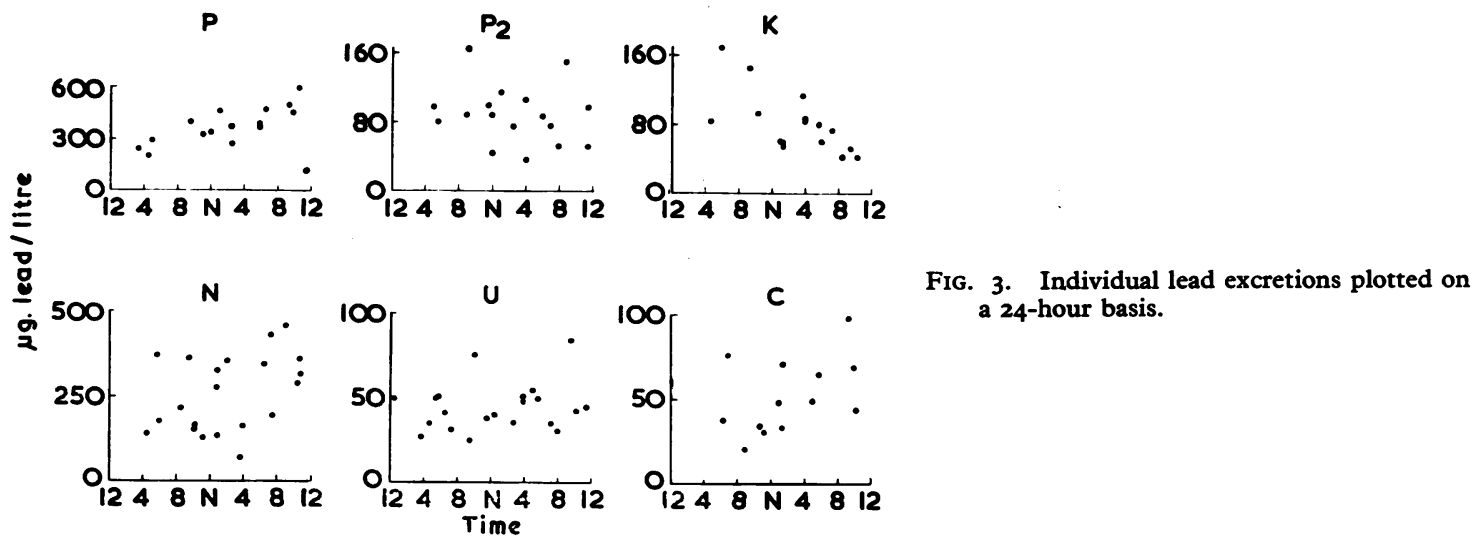

FIG. 4. Individual coproporphyrin excretions plotted on a 24 -hour basis.

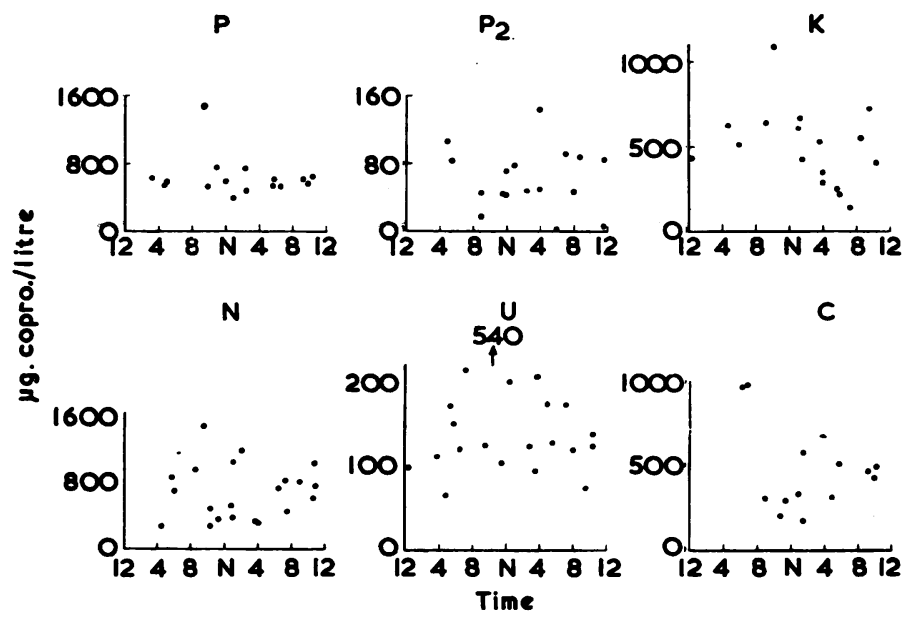

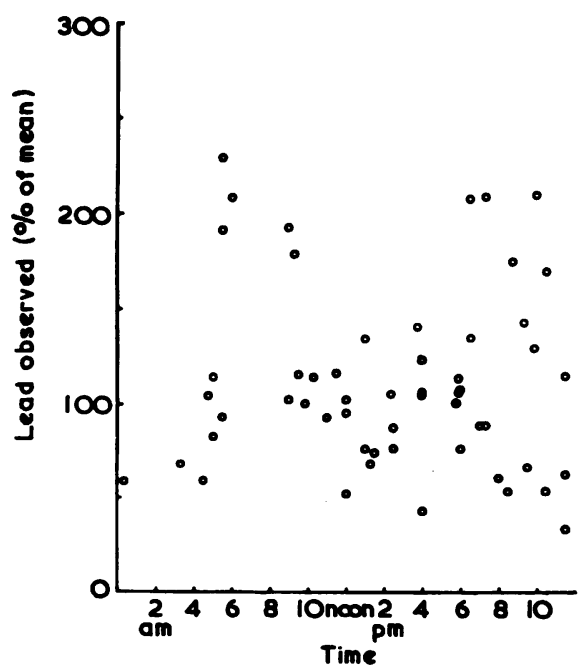

Fig. 5. Combined lead excretions expressed as ratios of 'mean concentration' plotted on a 24-hour basis. 

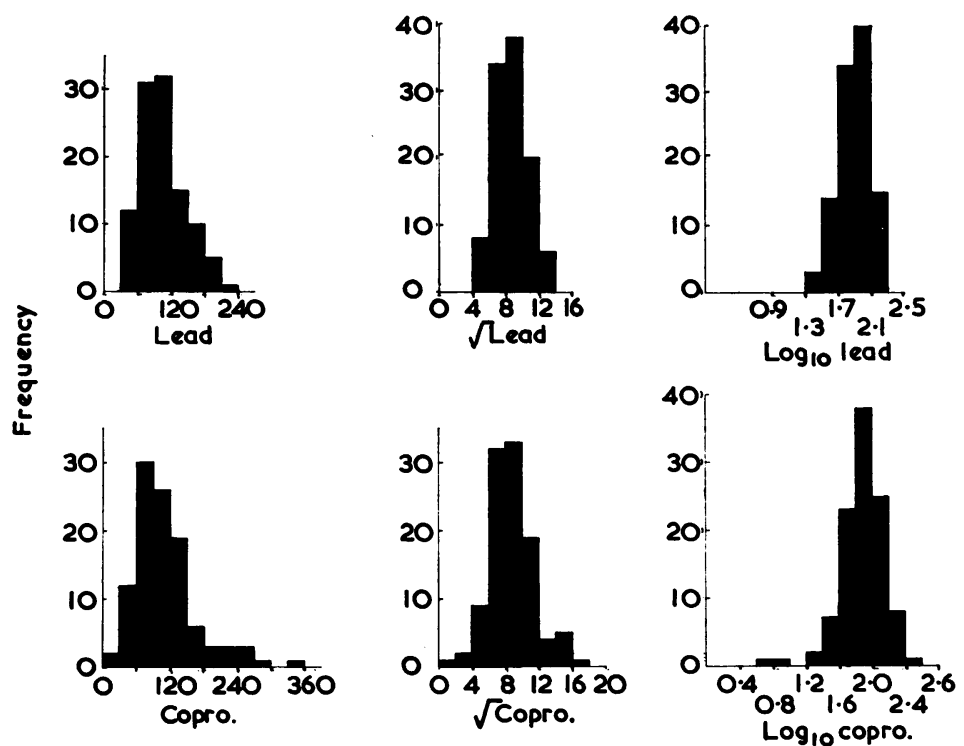

FIG. 7. Transformations of concentrations of lead and coproporphyrin expressed as a proportion of the 'mean concentration' of the man. (Each man contributes between 13 and 21 readings to each distribution.)

at a definite trend. When the scatter of the spot values about the 'mean concentration' is considered, it is found that there are insufficient data from any one man to arrive at a definite conclusion as to the shape of the distribution. By using the proportionate values, all the figures can be pooled to provide a sufficient number. In Fig. 7 it can be seen that the square roots of the proportions lie in an approximately normal distribution, whereas the proportions and the logarithms of the proportions fall in slightly skewed curves.

If the averages of a number of specimens are taken, these averages will be arranged about the arithmetical mean concentrations in a less skewed distribution, and the variability will be reduced by the factor $\mathrm{I} / \sqrt{n}$ where $n$ is the number of results providing the average. Thus, in order to obtain a reliable measure of the excretion level, the spot specimens must be considered collectively. This can be done either by statistical methods or by collecting cumulative samples of urine.

\section{Cumulative Samples}

A major difficulty in examining the reliability of cumulative urine samples as a method of assessing the lead absorption is to obtain an objective measure of the lead absorption of the individual. However, an indication can be gained by treating the man with chelating agents. Teisinger and Srbová (1959) and Rieders (1960), among others, have suggested that the lead excretion after the initial intravenous infusion of disodium calcium ethylenediaminetetraacetate (first $\mathrm{Pb}$ EDTA) provides a measure of the lead absorption. Cramér and Selander (1965) considered that 'a more or less objective measure' of the lead absorption was provided by the total weight of lead excreted in the urine during treatment with $9 \mathrm{~g}$. oral penicillamine by divided doses. When a leadworker is given chelating agents not only is there a dramatic rise in the urinary lead excretion but there is also a marked fall in the coproporphyrinuria. It appears that the decrease in the coproporphyrin excretion is related to the amount of lead excreted as the complex. A further indication of the lead absorption is thus provided by the 'excess' lead, which is the weight of lead excreted as the complex before the coproporphyrin excretion falls to a normal level (less than Ioo $\mu \mathrm{g}$. per day).

In this part of the work comparisons are made in the relationships between the pretreatment urine analyses and the lead absorption as measured by the first Pb EDTA and the 'excess' lead.

Experimental Data The subjects in this part of the investigation were hospital in-patients who had all been exposed to an industrial lead hazard. They all showed clinical evidence of excessive lead 
TABLE II

EXPERIMENTAL DATa

\begin{tabular}{|c|c|c|c|c|c|c|}
\hline \multirow[t]{3}{*}{ Patient } & \multicolumn{4}{|c|}{ Urinary Excretion } & \multirow{3}{*}{$\begin{array}{l}\text { First Pb EDTA } \\
\text { (mg.) }\end{array}$} & \multirow{3}{*}{$\begin{array}{l}\text { 'Excess' Lead } \\
\text { (mg.) }\end{array}$} \\
\hline & \multicolumn{2}{|l|}{ Lead } & \multicolumn{2}{|c|}{ Coproporphyrin } & & \\
\hline & $\mu g . / 24 h r$. & $\mu g . /$ litre & $\mu g . / 24 \mathrm{hr}$. & $\mu g . /$ litre & & \\
\hline A & 395 & 240 & $I, 415$ & 825 & IO'I & $37 \cdot I$ \\
\hline B & 700 & 7 io & 1,655 & 1,670 & $8 \cdot 4$ & $54 \cdot 8$ \\
\hline C & 100 & 50 & 790 & 405 & 3.6 & $10 \cdot 3$ \\
\hline D & 840 & 670 & - & - & $12 \cdot I$ & - \\
\hline E & 80 & 90 & 40 & 35 & - & Nil \\
\hline F & 120 & 75 & 415 & 255 & $6 \cdot 8$ & - \\
\hline G & $5 \mathrm{I}$ & 55 & Nil & $\mathrm{Nil}$ & 0.8 & Nil \\
\hline $\mathbf{H}$ & 195 & 125 & 445 & 280 & $5 \cdot 2$ & 8.9 \\
\hline I & - & - & - & - & 6.8 & $20 \cdot 3$ \\
\hline $\mathrm{J}$ & 270 & 150 & 785 & 425 & $8 \cdot 9$ & 35.4 \\
\hline $\mathrm{J}_{2}$ & 165 & 80 & 280 & 135 & $3 \cdot 2$ & $5 \cdot 4$ \\
\hline $\mathrm{J} 3$ & 93 & 46 & 255 & 125 & $2 \cdot 2$ & $2 \cdot 2$ \\
\hline $\mathbf{K}$ & 100 & 85 & 505 & 435 & $4 \cdot 3$ & $17 \cdot 8$ \\
\hline L & 540 & 705 & - & - & $3 \cdot 3$ & - \\
\hline $\mathbf{M}$ & 245 & 600 & 825 & 2,010 & $8 \cdot I$ & $22 \cdot 4$ \\
\hline $\mathbf{N}$ & 360 & 215 & 885 & 530 & $8 \cdot 8$ & 33.4 \\
\hline o & 415 & 185 & 1,870 & 845 & - & $29 \cdot 6$ \\
\hline $\mathbf{P}$ & 565 & 350 & 920 & 565 & - & $24 \cdot 2$ \\
\hline $\mathbf{Q}$ & 160 & 105 & 90 & 60 & - & Nil \\
\hline $\mathbf{R}$ & 165 & 80 & 395 & 190 & $3 \cdot 7$ & $6 \cdot 0$ \\
\hline $\mathbf{s}$ & 280 & 95 & 260 & 85 & - & $6 \cdot 2$ \\
\hline$T$ & 245 & 195 & 420 & 330 & $6 \cdot 1$ & 10.4 \\
\hline $\mathrm{U}$ & 125 & 60 & 295 & 140 & $5 \cdot 7$ & 5.7 \\
\hline V & 220 & 160 & 410 & 295 & 5.7 & $12 \cdot 2$ \\
\hline $\mathbf{W}$ & 145 & $5 \mathrm{I}$ & 125 & 40 & $3 \cdot 2$ & $4 \cdot 6$ \\
\hline
\end{tabular}

absorption. The 23 men were treated with intravenous infusions of disodium calcium EDTA. In addition, two men received oral disodium calcium EDTA and a further five men were given oral penicillamine medication. Twenty-four-hour urine samples were collected from each man before and throughout the regimen. The collections were timed to coincide with the administration of the drugs. The lead and coproporphyrin content of each sample was measured.

In Table II are shown the results of the analyses. The pretreatment lead and coproporphyrin levels are expressed in two ways: first, as the average excretion in $\mu \mathrm{g} . / 24$ hours and secondly as the mean concentration in $\mu \mathrm{g}$./litre. The pretreatment levels can be considered as screening tests since these values could have been measured while the man was in employment. The relationships between the screening tests and the first Pb EDTA and the 'excess' lead are shown as scatter diagrams in Figs. 8 and 9.

The results of correlation analyses (Table III) reveal that the excretion levels of lead and coproporphyrin indicate both the first $\mathrm{Pb}$ EDTA and the 'excess' lead. It is useful to consider which mode of expression of which metabolite provides the more reliable guide to the lead absorption. In Table III it can be seen that the results expressed as the daily excretions ( $\mu \mathrm{g}$. $/ 24$ hours) have higher correlations than those expressed as concentrations ( $\mu \mathrm{g}$./litre). Furthermore, the coproporphyrin correlation coefficients are higher than the corresponding lead values. To determine whether these differences are statistically significant, each correlation can be compared with all the others by an application of Duncan's multiple comparison method (James, I964). It is found that the 36 comparisons evolved from the nine correlation coefficients show no significant differences. This observation demonstrates that the degree of lead absorption is equally reflected by the lead and coproporphyrin urinary excretion levels, regardless of how the results are reported. Statistically significant differences might, of course, emerge if more patients were included in further studies.

The practical application of the above conclusions will now be considered. The hospital patients who provided the specimens were living under carefully 
TABLE III

Results of CoRrelation Analysis

Screening Test First Pb EDTA

'Excess' Lead

\begin{tabular}{llllll}
\hline$n$ & $r$ & $P$ & $n$ & $r$ & $P$ \\
\hline 19 & +0.69 & $<0.01$ & 21 & +0.84 & $<0.001$ \\
19 & +0.51 & $<0.05$ & 21 & +0.73 & $<0.001$ \\
17 & +0.77 & $<0.001$ & 21 & +0.88 & $<0.001$ \\
17 & +0.62 & $<0.01$ & 21 & +0.74 & $<0.001$ \\
& & & 17 & +0.82 & $<0.001$
\end{tabular}

First Pb EDTA (mg.)
( $\mu \mathrm{g} . / 24 \mathrm{hr}$.

( $\mu$ g. $/ 1$

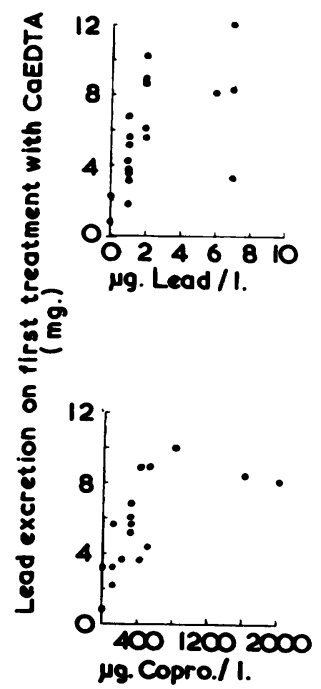

FIG. 8. Relationships between the screening tests and the first PbEDTA.
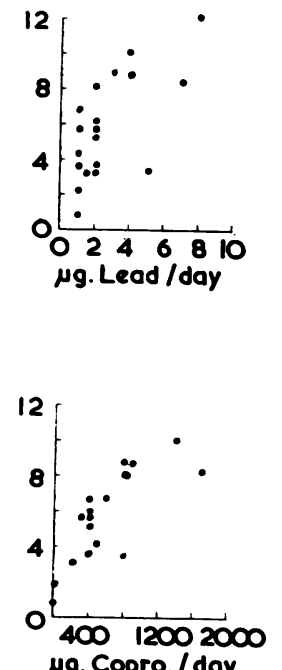

regulated conditions of environment, diet, fluid intake, etc. These conditions do not apply to active leadworkers. Molyneux (1964) demonstrated that the time a person spends at work influences the urinary concentrations of metabolites. Hence the values of the concentrations of workers will be different from those of hospital in-patients. Furthermore, given a constant exposure (in time and concentration) in two groups of men, the urinary concentrations of men working in comparable environmental conditions will be similar but the level will be different from that of men working under different environmental conditions. Hence a maximum urinary concentration deduced from men in one set of circumstances cannot be used to safeguard the health of all men working under any conditions. On the other hand, Cantarow and Trumper (1955) found that the normal kidney excretes the required amount of solids regardless of the quantity of water available (within wide limits) for their solution.

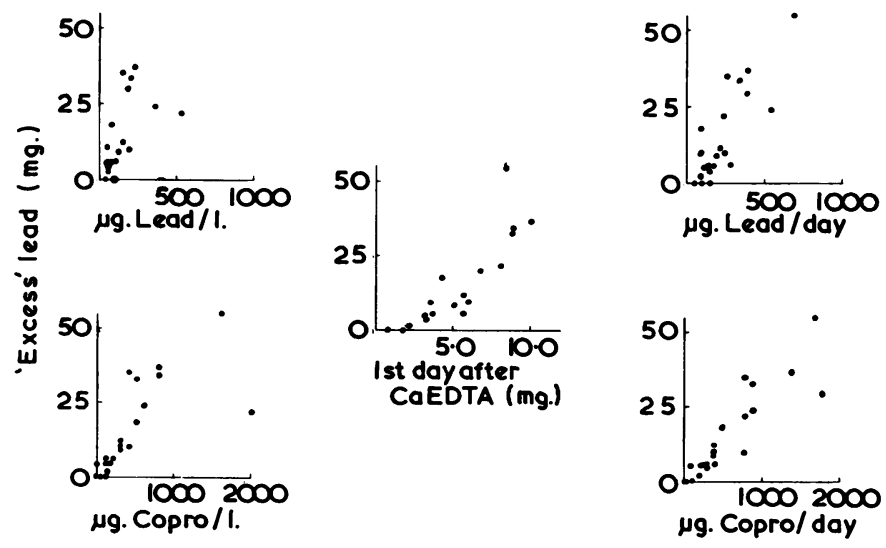

FIg. 9. Relationships between the screening tests and 'excess' lead. 
Therefore, it is valid to compare the daily excretion levels of men working under different conditions.

In conclusion it can be stated that, unless they are considered collectively, the results of single spot specimens are too variable to indicate the excretion levels of the metabolites. The urinary concentra- tions of lead and coproporphyrin, of people in comparable environmental conditions, reflect the lead absorption. The daily weight of metabolite eliminated possibly provides the more reliable guide to the lead absorption as the effects of environmental factors on the concentration are reduced.

\section{PART II: INTERPRETATION OF THE DATA}

It is suggested that leadworkers can be protected against absorbing an excessive quantity of lead by observing changes in the urinary excretions of lead or coproporphyrin. The collection of urine and the method of reporting the results should be standardized within each factory. A simple statistical method is described by which the mean excretion level and significant changes in that level can be deduced.

In 1949 Lane pointed out that, when the lead absorption of a group of men exceeds a certain level, cases of plumbism are likely to occur, but not necessarily in those individuals with the higher lead concentrations in the urine. Furthermore, Zielhuis (196Ib) found that if the maximum urinary concentration for coproporphyrin was taken as 4 on the 'Donath scale'-equivalent to $400 \mu \mathrm{g}$./litre-although $83 \%$ of workers with a haemoglobin concentration of less than $12.8 \mathrm{~g} . / 100 \mathrm{ml}$. would be detected, II \% of those with a haemoglobin level of more than $14.7 \mathrm{~g}$. $/ 100 \mathrm{ml}$. would also be compelled to discontinue their exposure. In Table II it can be seen that patient $W$ passed urine of which both the lead and coproporphyrin content fell within the non-exposed range, i.e., less than $60 \mu \mathrm{g}$. lead and $120 \mu \mathrm{g}$. coproporphyrin per litre of urine. Yet this same man exhibited several clinical signs and symptoms of excessive lead absorption. It seems that there is no lower limit for excreted metabolites below which clinical evidence of excessive lead absorption does not appear. This implies that to provide adequate protection for all men each man must be considered separately.

It can be assumed that the urinary excretion levels of lead and coproporphyrin, for each man, are related both to his exposure and to his absorption, and, further, that his absorption depends on his exposure. Provided that a man is in equilibrium with his exposure then his excretion levels of both metabolites will be constant, and if he is healthy then his condition will not deteriorate while his absorption remains constant. Different men tolerate lead differently, and the urinary excretion of metabolites depends on numerous factors. It appears that rather than compare each result with the M.U.C. it would be a more practicable method of screening the personnel to detect changes in the excretion levels. This in turn raises the problem of whether a change, which has occurred, is due to biological variation or is in fact due to a change in the hazard.

If specimens of about 4 litres of urine are taken the biological variation will be reduced to a minimum. However, the collection of these large specimens presents some difficulties when workpeople are allowed to contribute urine without supervision. Unless the personnel are of high integrity false or contaminated specimens are likely to be sent for analysis. This same objection applies equally to 24-hour urine collections. It is often more convenient to obtain a spot specimen when the man visits the medical centre.

Unfortunately, spot specimens show greater variability than any cumulative sample. Furthermore, the concentrations of metabolites tend to rise as the working day progresses. In addition, each individual has his own diurnal rhythm. So as to reduce these effects it is necessary that all specimens should be collected at a time specified in relation to the working period. Probably the best time would be at the beginning of the shift when the average excretion and hence the variability is at a minimum.

If a large number of spot specimens (about 30 to 40) are analysed during a period when the individual is in equilibrium with his environment, the biological variation can be measured. However, it was shown in Part I that the square roots of the concentrations fall in a normal distribution about the average excretion level. It is therefore possible to devise a quality control method, which, by providing estimates of the average and of the variability, will indicate statistically significant changes in the mean excretion level. The method described below was originally designed for the interpretation of spot specimens but can be applied to most screening tests. 


\section{The Theory of Quality Control as Applied to Screening Tests}

Provided that the man is in equilibrium with his environment his urinary excretion levels of lead and coproporphyrin will be constant. Suppose that the averages of groups of samples $\left(\overline{\mathbf{x}}_{1}, \overline{\mathbf{x}}_{2}, \overline{\mathbf{x}}_{3}, \ldots \overline{\mathbf{x}}_{k}\right)$ are plotted in order, how can it be judged whether their fluctuations about the mean level $(\overline{\mathbf{X}})$ are exceptional or not? Theory indicates that if the variation among the groups is uniform, $\overline{\mathbf{x}}$ should vary about $\overline{\mathbf{X}}$ with a standard error of $s / \sqrt{ }_{n}^{-}$, and further that the scatter is in accordance with the Normal Law of probability. It follows that it would be expected that:

50 averages in 1000 would fall above $\mathrm{X}+\mathrm{I} \cdot 645 \mathrm{~s} / \sqrt{n}$ 50 averages in 1000 would fall below $\bar{X}-\mathrm{I} \cdot 645 \mathrm{~s} / \sqrt{n}$ 25 averages in rooo would fall above $\mathbb{X}+\mathrm{I} \cdot 960 \mathrm{~s} / \sqrt{n}$ 25 averages in rooo would fall below $\mathrm{X}-\mathrm{I} \cdot 960 \mathrm{~s} / \sqrt{n}$ $I$ average in rooo would fall above $\mathrm{X}+3.09 \mathrm{~s} / \sqrt{n}$ $I$ average in I000 would fall below $\bar{X}-3.09 \mathrm{~s} / \sqrt{n}$ In other words,

$$
\begin{aligned}
& 90 \% \text { limits }=\bar{X} \pm A_{0050} s \\
& 95 \% \text { limits }=\bar{X} \pm A_{0.025} s \\
& 99.8 \% \text { limits }=\bar{X} \pm A_{0.001} s
\end{aligned}
$$

The calculation of each group average is easy but the calculation of every standard deviation is more laborious. For this reason it is the usual practice to base the estimation of the standard deviation on the group range, i.e., the difference between the highest and lowest readings of any one group. Where each group contains the same number of samples the following equation can be used to estimate the standard deviation:

Se $=\frac{\mathrm{I}}{\mathrm{d}_{\mathrm{n}}} \cdot \frac{\mathrm{I}}{\mathrm{k}}\left(\mathrm{w}_{1}+\mathrm{w}_{2}+\mathrm{w}_{3}+\ldots \mathrm{w}_{\mathrm{k}}\right)=\frac{\mathrm{I}}{\mathrm{d}_{\mathrm{n}}} \cdot \overline{\mathrm{W}}$ where $\mathrm{Se}$ is the estimated standard deviation, $\frac{I}{d_{n}}$ is the factor for converting the average range to the standard deviation, $\mathrm{k}$ is the number of groups, $w$ is the range of each group, and $W$ is the average range.

By using this equation a little of the available information is lost, but as each group is only a check on the mean excretion level the moderate loss is more than compensated for by the time saved in the routine calculation of the standard deviation. The two equations can be combined thus:

$$
\begin{aligned}
& 90 \% \text { limits }=\bar{X} \pm A_{0.050} \cdot \frac{I}{d_{n}} \cdot \bar{W} \\
& 95 \% \text { limits }=\mathbb{X} \pm A_{0.025} \cdot \frac{I}{d_{n}} \cdot \bar{W} \\
& 99.8 \% \text { limits }=\mathbb{X} \pm A_{0.001} \cdot \frac{I}{d_{n}} \cdot \bar{W}
\end{aligned}
$$

All these constants are shown in Table IV.
TABLE IV

Statistical Factors For Estimating the Standard Deviation and Limits

\begin{tabular}{cccc}
$\begin{array}{l}\text { No. of Samples } \\
\text { in Group }\end{array}$ & $\frac{\mathbf{A}_{0.001}}{\mathbf{d}_{\mathbf{n}}}$ & $\frac{\mathbf{A}_{0.025}}{\mathbf{d}_{\mathbf{n}}}$ & $\frac{\mathbf{A}_{0.050}}{\mathrm{~d}_{\mathbf{n}}}$ \\
\hline 2 & $\mathbf{1} \cdot 936$ & $\mathbf{1} \cdot 228$ & $\mathbf{1} \cdot 0307$ \\
3 & $\mathbf{I} \cdot 054$ & 0.669 & 0.5613 \\
4 & 0.750 & 0.476 & 0.3997 \\
5 & 0.594 & 0.377 & 0.3164 \\
6 & 0.498 & 0.316 & 0.2648 \\
7 & 0.432 & 0.274 & 0.2300 \\
8 & 0.384 & 0.243 & 0.2044 \\
9 & 0.347 & 0.220 & 0.1845 \\
10 & 0.317 & 0.201 & 0.1689
\end{tabular}

This table has been compiled from data according to Pearson (1935), Davies (1949), and Moroney (1953).

The Control Method From the above theory a simple method has been devised. The method indicates the excretion level and the $90 \%$ confidence limits from groups of four consecutive samples. The average of four samples was chosen because the $90 \%$ limits can be estimated by multiplying the average range by 0.3997 (which for practical purposes is $4 / 10$ ). In this scheme, significant changes in the level are indicated when any independent group average exceeds the limits deduced from previous groups. Since the method was designed for routine investigations the observed results are used instead of the square roots of the concentrations. The method is still applicable, however. As the limits are arranged symmetrically about the mean level more than one average in 20 would be expected to lie above the upper limit and less than one in 20 below the lower limit, although only one in ro would fall beyond either limit. The loss in accuracy is more than offset by the time saved and by reducing the arithmetical errors which could arise. For work of higher precision the square roots of the concentrations could be used.

It is usual to collect the samples at weekly, monthly, or even longer intervals. Hence there is a long period when little information can be deduced. Since it would be wasteful to ignore each result until a complete group has been collected, the moving average (the average of the four latest results) is used to monitor the excretion level until the group is complete. If this scheme is compared with the usual technique the moving average replaces the spot result and the upper confidence limit replaces the M.U.C. Thus each man can be protected without defining a generally applicable M.U.C.

The Record Form and Chart The method consists of entering the results in a record form (Tables V and VI) and plotting a chart (Figs. IO and II). 
TABLE V

Coproporphyrin Concentrations ( $\mu$ g./1.) OF URINe SPot SPECimens Collected From Subject A OVER A PERIOD OF 24 MONTHS

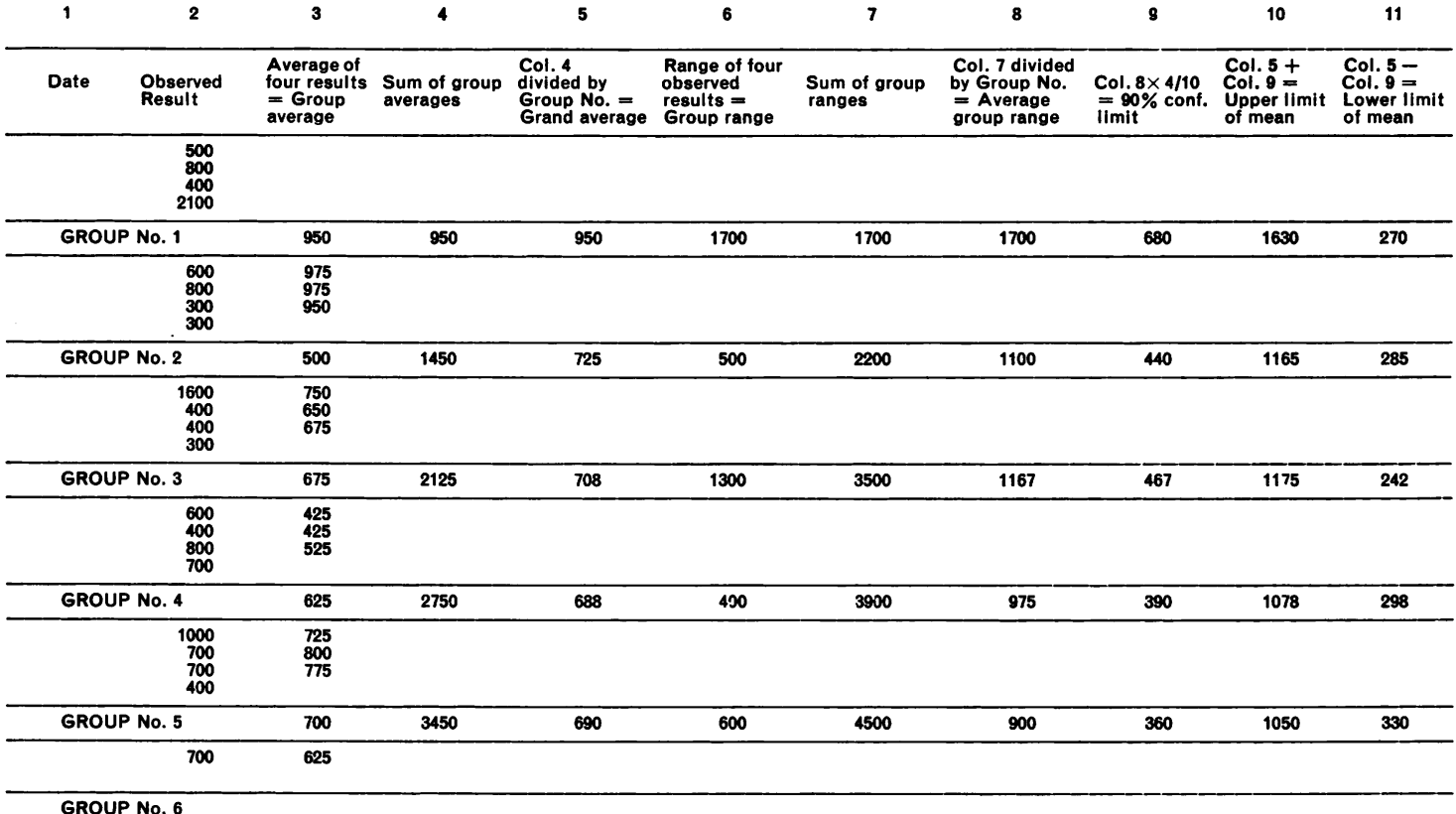

TABLE VI

Coproporphyrin Concentrations ( $\mu \mathrm{g}$./1.) of Urine Spot Specimens Collected from Subject B OVER A PERIOD OF I5 MONTHS

\begin{tabular}{|c|c|c|c|c|c|c|c|c|c|c|}
\hline Date & $\begin{array}{l}\text { Observed } \\
\text { Result }\end{array}$ & $\begin{array}{l}\text { Average of } \\
\text { four results } \\
=\text { Group } \\
\text { average }\end{array}$ & $\begin{array}{l}\text { Sum of group } \\
\text { averages }\end{array}$ & $\begin{array}{l}\text { Col. } 4 \\
\text { divided by } \\
\text { Group No. }= \\
\text { Grand average }\end{array}$ & $\begin{array}{l}\text { Range of four } \\
\text { observed } \\
\text { results = } \\
\text { Group range }\end{array}$ & $\begin{array}{l}\text { Sum of group } \\
\text { ranges }\end{array}$ & $\begin{array}{l}\text { Col. } 7 \text { divided } \\
\text { by Group No. } \\
\text { Average } \\
\text { group range }\end{array}$ & $\begin{array}{l}\text { Col. } 8 \times 4 / 10 \\
=90 \% \text { cont. } \\
\text { limit }\end{array}$ & $\begin{array}{l}\text { Col. } 5+ \\
\text { Col. } 9= \\
\text { Upper limit } \\
\text { of mean }\end{array}$ & $\begin{array}{l}\text { Col. } 5- \\
\text { Col. } 9= \\
\text { Lower limit } \\
\text { of mean }\end{array}$ \\
\hline & $\begin{array}{l}200 \\
200 \\
200 \\
200\end{array}$ & & & & & & & & & \\
\hline \multicolumn{2}{|c|}{ GROUP No. 1} & 200 & 200 & 200 & 0 & 0 & 0 & 0 & 200 & 200 \\
\hline & $\begin{array}{l}200 \\
200 \\
200 \\
300\end{array}$ & $\begin{array}{l}200 \\
200 \\
200 \\
225\end{array}$ & & & & & & & & \\
\hline \multicolumn{2}{|c|}{ GROUP No. 2} & 225 & 425 & 213 & 100 & 100 & 50 & 20 & 233 & 193 \\
\hline & $\begin{array}{l}400 \\
300 \\
200 \\
700\end{array}$ & $\begin{array}{l}275 \\
300 \\
300 \\
400\end{array}$ & & & & & & & & \\
\hline
\end{tabular}

REASSESS

GROUP No. 3 BECOMES GROUP No. 1

\begin{tabular}{|c|c|c|c|c|c|c|c|c|c|c|}
\hline & $\begin{array}{l}400 \\
300 \\
200 \\
700\end{array}$ & $\begin{array}{l}275 \\
300 \\
300 \\
400\end{array}$ & & & & & & & & \\
\hline \multicolumn{2}{|l|}{ GROUP No. 1} & 400 & 400 & 400 & 500 & 500 & 500 & 200 & 600 & 200 \\
\hline & $\begin{array}{l}600 \\
400 \\
200 \\
800\end{array}$ & $\begin{array}{l}450 \\
475 \\
475 \\
500\end{array}$ & & & & & & & & \\
\hline GROUP No. 2 & & 500 & 900 & 450 & 600 & 1100 & 550 & 220 & 670 & 230 \\
\hline
\end{tabular}




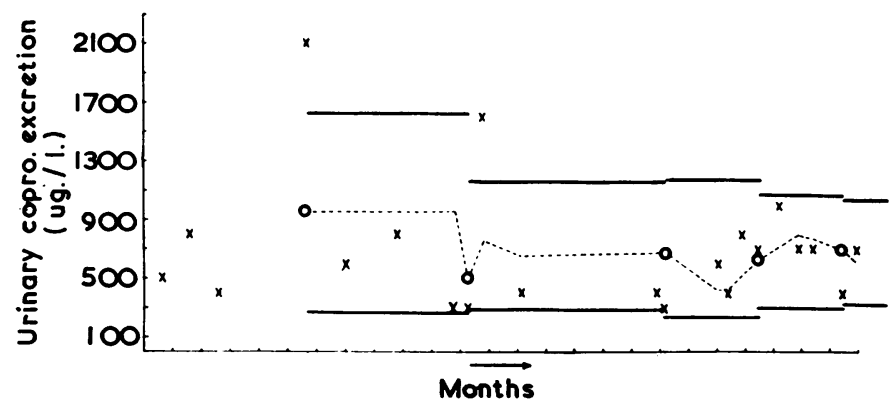

Fig. 10. The record chart of subject $A: x$, observed result; $O$, group mean; - - - moving average; $-90 \%$ confidence limits.

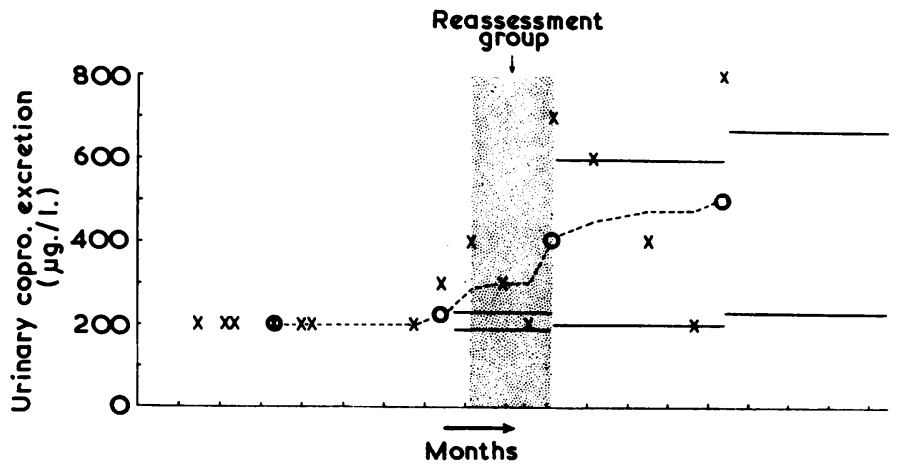

FIG. II. The record chart of subject B: $x$, observed result; $O$, group mean; - - - moving average; $-90 \%$ confidence limits.

The record form consists of I I columns divided into groups of four down the page. The first column is for the date which fixes the points on the ordinate of the chart. The second column shows the observed results. The moving average of four consecutive results is placed in column three. The remainder of the columns can only be used with independent groups of four results. Column 4 shows the sum of the independent group averages which, when divided by the number of groups, gives the grand average of all the observed results, and this is placed in column 5. The next four columns are used to calculate the $90 \%$ confidence limits. Column 6 shows the range (the difference between the highest and the lowest in the group). Column 7 shows the sum of the ranges which when divided by the number of groups gives the average range. This is placed in column 8 . In column 9, the average range is multiplied by $4 / 10$ to convert the average range to $90 \%$ confidence limit. Column ro gives the grand mean (column 5) plus the limit value, and column II gives the grand mean minus the limit value, thus giving the upper and lower confidence limits.

Interpretation of the Record Form and Chart Figures IO and II were derived from the data in Tables V and VI which were obtained from an anonymous firm. The charts were plotted from the values in columns 1,3 , ro, and II. The moving average is shown as a broken line. The open circles are the independent group averages, and the horizontal full lines are the confidence limits. In these figures the spot results, shown as ' $\mathrm{Xs}$ ', have been included for comparison. * In Fig. Io are shown the results of one man. As the results were obtained and the chart built up it was seen that his excretion level remained constant. The precision of both the grand mean and the limits increased as more data were collected.

It will be noted that although this man appears to be excreting an exorbitant quantity of coproporphyrins, he was healthy throughout this period (haemoglobin never below $14.7 \mathrm{~g} . / 100 \mathrm{ml}$.). However, he was working under adverse conditions and usually passed small volumes of concentrated urine.

Figure II shows the results of a man with an excretion level stable for eight months followed by a rise over the remaining period. The spot results (shown as ' $\mathrm{Xs}$ ') are difficult to interpret but the moving average (the broken line) demonstrates a continual upward trend. In Table VI the upper limit

* It must be remembered that the confidence limits apply only to means of 4 ; individual spot specimen results will often fall outside these limits, without signifying a change in the man's excretion level. 
of the first two groups (column 10) is exceeded by the first and subsequent moving averages of the third group. If this scheme had been in operation at the time, the samples to complete the group would have been collected at shorter intervals. Although the observed results (' $\mathrm{Xs}$ ') point to a return to the low level, the third group average is significantly higher than the previous averages. This result could have been a chance observation but it is essential to consider each rise above the limit as being due to some ascribable reason before attributing it to chance. In fact the man had moved to a different department and was found to be healthy so he was allowed to remain at the new job. Since the man has a higher excretion level the results of the first two groups cannot be used with the latter values, so a new series begins. This notion of discarding all the results of a previous stable period must be adopted since the scatter and hence the limits depend on the excretion level (see Part I). If this is not done, when the level rises the limits will be too close together; conversely, when the level falls the limits will be too wide apart. This will make it more difficult to detect changes in the excretion levels.

Provided a standard procedure is adopted for the collection of the urine and the manner in which the results are expressed, this scheme will indicate significant changes in the excretion levels. Considerable care is needed in the interpretation of the data. It is possible to detect a significant fall in the metabolite concentration yet the man may be exposed to a greater hazard. One circumstance in which this paradoxical situation could arise is when a man, who has been in equilibrium with an extremely hot thermal environment at low risk and is then transferred to a normal environment at a higher risk, has specimens collected towards the end of the shift. It is apparent that some more reliable guide to the lead absorption must be measured, as well as having the man clinically examined, whenever a significant change in the metabolite level is detected and whenever the man changes his job.

The author is indebted to Professor R. C. Browne for permission to publish this paper; to Dr. J. Steel for general supervision of the work and many stimulating discussions; to Dr. R. I. McCallum for providing the subjects; to Dr. D. J. Newell for statistical advice; to
Mrs. D. Weightman for preparing the diagrams; and to Mrs. M. Bell and Miss S. Lowes for technical assistance.

\section{REFERENCES PARTS I AND II}

Barnes, E. C. (1939). f. industr. Hyg., $21,464$.

Bleiler, R. A., and Schedl, H. P. (1962). F. Lab. clin. Med., 59, 945.

Buchwald, H. (1964). Ann. occup. Hyg., 7, 125.

- (1965). Ibid., 8, 265.

Cantarow, A., and Trumper, M. (1955). Clinical Biochemistry, 5th ed., p. 570. Saunders, Philadelphia.

Cramér, K., and Selander, S. (1965). Brit. F. industr. Med., 22, 3 I I.

Davies, O. L. (1949). Statistical Methods in Research and Production, 2nd ed. p. 21 I. Oliver and Boyd, London.

Dick, J. M., Ellis, R. W., and Steel, J. (1961). Brit. F. industr. Med., 18, 283.

Elkins, H. B. (196I). Proceedings of the International Symposium on Maximum Allowable Concentrations of Toxic Substances in Industry, Prague, 1959, p. 271. Butterworth, London.

Hamlin, L. E., and Weber, H. J. (1947). F. industr. Hyg., 29, 367.

James, J. W. (1964). Appl. Statistics (F. roy. statist. Soc. C.), $13,127$.

Kehoe, R. A., Cholak, J., Hubbard, D. M., Bambach, K., McNary, R. M., and Story, R. V. (I940). F. industr. Hyg., 22, 381.

Lane, R. E. (1949). Brit. F. industr. Med., 6, I25.

Levine, L., and Fahy, J. P. (1945). F. industr. Hyg., 27, 217.

Molyneux, M. K. B. (1964). Brit. F. industr. Med., 21, 203.

Moroney, M. J. (1953). Facts from Figures, 2nd ed. p. 162. Penguin Books, London.

Pearson, E. G. (1935). British Standard 600, 1935. p. 85. British Standards Institution, London.

Pinto, S. S., Elkins, H. B., and Ege, J. F., Jr. (I94I). $\mathcal{f}$. industr. Hyg., 23, 313.

Price, J. W., Miller, M., and Hayman, J. M., Jr. (1940). $\mathcal{F}$. clin. Invest., 19, 537.

Rainsford, S. G. (I96I). Proceedings Thirteenth International Congress on Occupational Health, 1960, p. 345. Book Associates, New York.

Rieders, F. (1960). Metal-Binding in Medicine, Proc. Symposium, Hahnemann Medical College, Philadelphia, ed. Seven, M. J., p. 143. Lippincott, Philadelphia.

Rimington, C., and Sveinsson, S. L. (1950). Scand. F. clin. Lab. Invest., 2, 209.

Schoen, E. J., Young, G., and Weissman, A. (1959). F. Lab. clin. Med., 54, 277.

Smith, J. C., and Kench, J. E. (1957). Brit. f. industr. Med., $14,240$.

Teisinger, J., and Srbová, J. (1959). Ibid., 16, 148.

Varley, H. (1962). Practical Clinical Biochemistry, 3rd ed., p. 15I. Heinemann, London.

Zielhuis, R. L. (196ra). Brit. F. industr. Med., 18, 58.

(196rb). International Symposium on Maximum Allowable Concentrations of Toxic Substances in Industry, Prague, 1959, p. 293. Butterworth, London. 


\section{APPENDIX}

TABLE AI

Observed Results from Spot Urine Specimens: Patient C

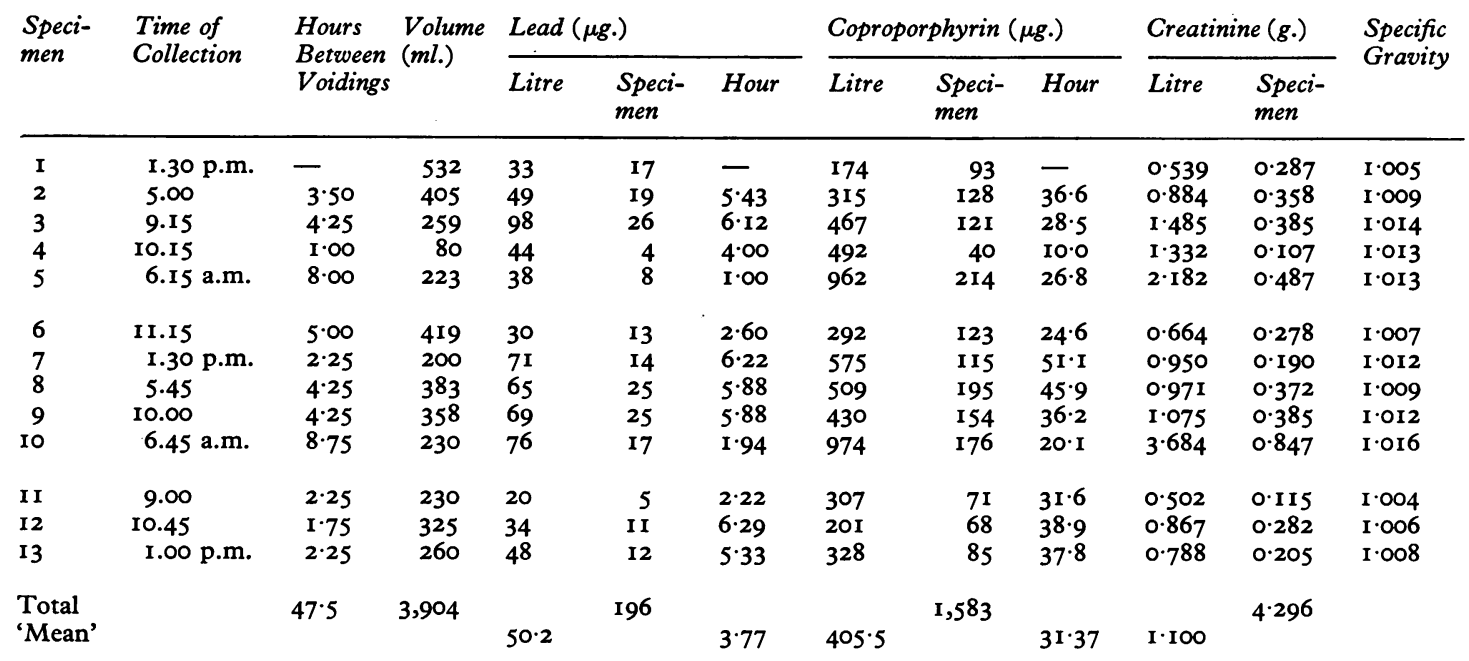

TABLE AII

Observed Results from Spot Urine Specimens: Patient $\mathrm{K}$

\begin{tabular}{|c|c|c|c|c|c|c|c|c|c|c|c|c|}
\hline \multirow{2}{*}{$\begin{array}{l}\text { Speci- } \\
\text { men }\end{array}$} & \multirow{2}{*}{$\begin{array}{l}\text { Time of } \\
\text { Collection }\end{array}$} & \multirow{2}{*}{$\begin{array}{l}\text { Hours } \\
\text { Between } \\
\text { Voidings }\end{array}$} & \multirow{2}{*}{$\begin{array}{l}\text { Volume } \\
(m l .)\end{array}$} & \multicolumn{3}{|c|}{ Lead $(\mu g)}$. & \multicolumn{3}{|c|}{ Coproporphyrin ( $\mu g)}$. & \multicolumn{2}{|c|}{ Creatinine (g.) } & \multirow{2}{*}{$\begin{array}{l}\text { Specific } \\
\text { Gravity }\end{array}$} \\
\hline & & & & Litre & $\begin{array}{l}\text { Speci- } \\
\text { men }\end{array}$ & Hour & Litre & $\begin{array}{l}\text { Speci- } \\
\text { men }\end{array}$ & Hour & Litre & $\begin{array}{l}\text { Speci- } \\
\text { men }\end{array}$ & \\
\hline $\mathbf{I}$ & I.00 p.m. & 一 & 92 & 61 & 6 & - & 605 & 57 & - & $I \cdot 54 I$ & 0.142 & $1 \cdot 024$ \\
\hline 2 & 4.00 & 3.00 & 87 & 84 & 7 & $2 \cdot 33$ & 353 & 31 & $10 \cdot 3$ & 0.932 & 0.080 & $1 \cdot 018$ \\
\hline 3 & 7.15 & $3 \cdot 25$ & 390 & 72 & 28 & $8 \cdot 60$ & 139 & 55 & $16 \cdot 9$ & 0.340 & 0.134 & $1 \cdot 008$ \\
\hline 4 & I0.15 a.m. & $15 \cdot 00$ & 75 & 93 & 7 & 0.47 & I,090 & 72 & $4 \cdot 8$ & - & - & $I \cdot 025$ \\
\hline 5 & I.I5 p.m. & 3.00 & 124 & 55 & 7 & $2 \cdot 33$ & 671 & 83 & $27 \cdot 7$ & 0.995 & 0.124 & $1 \cdot 027$ \\
\hline 6 & 3.45 & $2 \cdot 50$ & 223 & 114 & 25 & $10 \cdot 00$ & 529 & I 18 & $42 \cdot 9$ & 0.900 & 0.201 & $1 \cdot 023$ \\
\hline 7 & 5.45 & $2 \cdot 00$ & 185 & 81 & 15 & $7 \cdot 50$ & 253 & 47 & $23 \cdot 5$ & 0.850 & 0.157 & $I \cdot 020$ \\
\hline 8 & 8.30 & $2 \cdot 75$ & 193 & 43 & 8 & $2 \cdot 90$ & 549 & 106 & $38 \cdot 5$ & 0.916 & 0.177 & $I \cdot 027$ \\
\hline 9 & 10.30 & $2 \cdot 00$ & 90 & 43 & 4 & $2 \cdot 00$ & 405 & 37 & $18 \cdot 5$ & $\mathbf{I} \cdot 387$ & 0.125 & $1 \cdot 028$ \\
\hline 10 & 6.00 a.m. & 7.50 & 180 & 169 & 30 & $4 \cdot 00$ & 511 & 92 & $12 \cdot 3$ & $I \cdot 181$ & 0.212 & $I \cdot 022$ \\
\hline I I & 9.15 & $3 \cdot 25$ & 133 & 145 & 19 & $5 \cdot 80$ & 643 & 86 & $26 \cdot 5$ & $1 \cdot 550$ & 0.206 & I.025 \\
\hline 12 & I.30 p.m. & $4 \cdot 25$ & 185 & 60 & I I & $2 \cdot 60$ & 424 & 79 & $18 \cdot 6$ & 0.770 & 0.238 & $1 \cdot 022$ \\
\hline 13 & 4.00 & $2 \cdot 50$ & 425 & 86 & 37 & $14 \cdot 80$ & 290 & 123 & $49 \cdot 2$ & 0.420 & 0.179 & $1 \cdot 015$ \\
\hline 14 & 6.00 & 2.00 & 271 & $6 I$ & 17 & $8 \cdot 50$ & 219 & 59 & $29 \cdot 5$ & 0.580 & 0.157 & $1 \cdot 014$ \\
\hline 15 & 9.30 & 3.50 & 120 & 53 & 6 & $1 \cdot 67$ & 726 & 87 & $24 \cdot 9$ & $I \cdot I 44$ & 0.137 & $1 \cdot 026$ \\
\hline 16 & I2.15 a.m. & $2 \cdot 75$ & 242 & 48 & 12 & 4.40 & 432 & 105 & $38 \cdot 2$ & 1.005 & 0.243 & $1 \cdot 023$ \\
\hline I7 & 4.45 & 4.50 & 290 & 84 & 24 & $5 \cdot 30$ & 620 & 180 & $40 \cdot 0$ & $I \cdot I 8 I$ & 0.342 & $1 \cdot 025$ \\
\hline \multirow{2}{*}{$\begin{array}{l}\text { Total } \\
\text { 'Mean' }\end{array}$} & & \multirow[t]{2}{*}{$63 \cdot 75$} & \multirow[t]{2}{*}{3,305} & \multirow{2}{*}{\multicolumn{3}{|c|}{263}} & \multicolumn{3}{|c|}{1,417} & \multirow{2}{*}{\multicolumn{2}{|c|}{$2 \cdot 854$}} & \\
\hline & & & & & & & 429 & & $21 \cdot 33$ & & & \\
\hline
\end{tabular}


TABLE AIII

\begin{tabular}{|c|c|c|c|c|c|c|c|c|c|c|c|c|}
\hline \multirow{3}{*}{$\begin{array}{l}\text { Speci- } \\
\text { men }\end{array}$} & \multirow{3}{*}{$\begin{array}{l}\text { Time of } \\
\text { Collection }\end{array}$} & \multicolumn{10}{|c|}{ Observed Results from Spot Urine Specimens: Patient N } & \multirow{3}{*}{$\begin{array}{l}\text { Specific } \\
\text { Gravity }\end{array}$} \\
\hline & & \multirow{2}{*}{$\begin{array}{l}\text { Hours } \\
\text { Between } \\
\text { Voidings }\end{array}$} & \multirow{2}{*}{$\begin{array}{l}\text { Volume } \\
(\mathrm{ml} .)\end{array}$} & \multicolumn{3}{|c|}{ Lead $(\mu g)}$. & \multicolumn{3}{|c|}{ Coproporphyrin ( $\mu g)}$. & \multicolumn{2}{|c|}{ Creatinine $(g)}$. & \\
\hline & & & & Litre & $\begin{array}{l}\text { Speci- } \\
\text { men }\end{array}$ & Hour & Litre & $\begin{array}{l}\text { Speci- } \\
\text { men }\end{array}$ & Hour & Litre & $\begin{array}{l}\text { Speci- } \\
\text { men }\end{array}$ & \\
\hline $\mathbf{I}$ & 2.00 p.m. & - & 60 & 354 & 25 & - & 1,164 & 72 & - & I·194 & 0.072 & $\mathrm{I} \cdot 028$ \\
\hline 2 & 7.15 & $5 \cdot 25$ & 273 & 437 & II9 & $22 \cdot 7$ & 814 & 222 & $42 \cdot 3$ & 0.762 & 0.208 & $1 \cdot 023$ \\
\hline 3 & 10.30 & 3.25 & 233 & 292 & 68 & $20 \cdot 9$ & 504 & 118 & $36 \cdot 3$ & $I \cdot 205$ & $0.28 \mathrm{I}$ & I.019 \\
\hline 4 & 6.00 a.m. & $7 \cdot 50$ & 286 & 177 & 51 & $6 \cdot 8$ & 687 & 197 & $26 \cdot 3$ & - & - & $1 \cdot 018$ \\
\hline 5 & 8.30 & $2 \cdot 50$ & 98 & 214 & 22 & $8 \cdot 8$ & 937 & 92 & $36 \cdot 9$ & $1 \cdot 134$ & 0.111 & $1 \cdot 020$ \\
\hline 6 & I0.15 & $\mathrm{I} \cdot 75$ & 260 & 166 & 35 & $20 \cdot 0$ & 265 & 69 & 39.4 & - & - & $1 \cdot 009$ \\
\hline 7 & r.00 p.m. & $2 \cdot 25$ & 355 & 134 & 48 & $21 \cdot 3$ & 374 & 133 & $59 \cdot 1$ & - & - & $1 \cdot 009$ \\
\hline 8 & 3.45 & $2 \cdot 75$ & 515 & 70 & 36 & I3. I & 324 & 167 & $60 \cdot 7$ & 0.286 & 0.147 & $1 \cdot 007$ \\
\hline 9 & $7 \cdot 30$ & 3.75 & 315 & 196 & 63 & 16.8 & 442 & 139 & 50.5 & 0.430 & 0.135 & I.012 \\
\hline I0 & 10.45 & $3 \cdot 25$ & 184 & 319 & 59 & $18 \cdot 2$ & 758 & 140 & $43 \cdot I$ & 0.645 & 0.119 & $1 \cdot 020$ \\
\hline I I & 5.45 a.m. & $7 \cdot 00$ & I8I & 371 & 67 & $9 \cdot 6$ & 846 & 153 & $21 \cdot 9$ & 0.838 & 0.152 & - \\
\hline 12 & 9.30 & $3 \cdot 75$ & II6 & 363 & 42 & II $\cdot 2$ & I,445 & 168 & $44 \cdot 8$ & 0.352 & 0.041 & $I \cdot 024$ \\
\hline 13 & II.15 & $I \cdot 75$ & 200 & 127 & 26 & 14.9 & 354 & 71 & $40 \cdot 6$ & 0.855 & 0.171 & $1 \cdot 007$ \\
\hline 14 & I.00 p.m. & $\mathrm{I} \cdot 75$ & 123 & 329 & 40 & $22 \cdot 9$ & 1,031 & 127 & $72 \cdot 6$ & 0.606 & 0.074 & $1 \cdot 015$ \\
\hline 15 & 4.00 & $3 \cdot 00$ & 542 & 162 & 88 & $29 \cdot 3$ & 312 & 170 & $56 \cdot 7$ & $I \cdot 469$ & 0.796 & - \\
\hline 16 & 6.30 & $2 \cdot 50$ & 158 & 345 & 55 & $22 \cdot 0$ & 713 & 113 & $45 \cdot 2$ & $I \cdot 246$ & 0.197 & $1 \cdot 020$ \\
\hline 17 & 9.00 & $2 \cdot 50$ & 131 & 460 & 60 & $24 \cdot 0$ & 796 & 104 & $4 I \cdot 6$ & $1 \cdot 283$ & 0.168 & $1 \cdot 022$ \\
\hline 18 & 10.45 & $\mathrm{I} \cdot 75$ & 70 & 361 & 26 & 14.9 & I,OIO & 71 & $40 \cdot 6$ & 0.364 & 0.025 & - \\
\hline I9 & 4.30 a.m. & $5 \cdot 75$ & 545 & 140 & 76 & $13 \cdot 2$ & 278 & 152 & $26 \cdot 4$ & 0.838 & 0.457 & $1 \cdot 012$ \\
\hline 20 & 10.15 & $5 \cdot 75$ & 234 & 151 & 36 & $6 \cdot 3$ & 480 & 112 & 19.5 & 0.867 & 0.203 & I.OIO \\
\hline 21 & I2.45 p.m. & 2.50 & 133 & 279 & 37 & $14 \cdot 8$ & 506 & 67 & $26 \cdot 8$ & 0.645 & 0.086 & $1 \cdot 017$ \\
\hline $\begin{array}{l}\text { Total } \\
\text { 'Mean', }\end{array}$ & & $70 \cdot 25$ & 5,021 & 214 & I,079 & 15.00 & 529 & 2,657 & 36.80 & 0.836 & $3 \cdot 443$ & \\
\hline
\end{tabular}

TABLE AIV

Observed Results from Spot URine Specimens: Patient P

\begin{tabular}{|c|c|c|c|c|c|c|c|c|c|c|c|c|}
\hline \multirow{2}{*}{$\begin{array}{l}\text { Speci- } \\
\text { men }\end{array}$} & \multirow{2}{*}{$\begin{array}{l}\text { Time of } \\
\text { Collection }\end{array}$} & \multirow{2}{*}{$\begin{array}{l}\text { Hours } \\
\text { Between } \\
\text { Voidings }\end{array}$} & \multirow{2}{*}{$\begin{array}{l}\text { Volume } \\
(\mathrm{ml} .)\end{array}$} & \multicolumn{3}{|c|}{ Lead ( $\mu g)}$. & \multicolumn{3}{|c|}{ Coproporphyrin ( $\mu g)}$. & \multicolumn{2}{|c|}{ Creatinine (g.) } & \multirow{2}{*}{$\begin{array}{l}\text { Specific } \\
\text { Gravity }\end{array}$} \\
\hline & & & & Litre & $\begin{array}{l}\text { Speci- } \\
\text { men }\end{array}$ & Hour & Litre & $\begin{array}{l}\text { Speci- } \\
\text { men }\end{array}$ & Hour & Litre & $\begin{array}{l}\text { Speci- } \\
\text { men }\end{array}$ & \\
\hline $\mathbf{I}$ & 9.50 a.m. & - & 316 & 350 & III & - & 518 & 182 & - & 0.813 & 0.257 & I.or 4 \\
\hline 2 & I. .0 p.m. & $3 \cdot 16$ & 366 & 460 & 168 & 53 & 385 & 141 & 45 & 0.421 & 0.154 & I·OII \\
\hline 3 & 6.30 & 5.50 & 250 & 470 & 118 & 22 & 528 & 132 & 24 & 0.898 & 0.225 & I.019 \\
\hline 4 & 9.15 & $2 \cdot 75$ & 231 & 498 & 115 & 42 & 610 & 141 & 51 & 0.789 & 0.245 & r.org \\
\hline 5 & 3.15 a.m. & $6 \cdot 00$ & 318 & 238 & 76 & I3 & 627 & 199 & 33 & $1 \cdot 098$ & 0.349 & $1 \cdot 013$ \\
\hline 6 & 11.00 & $7 \cdot 75$ & 281 & 324 & 9I & Io & 750 & 211 & 24 & 0.947 & 0.266 & I.013 \\
\hline 7 & 2.20 p.m. & $3 \cdot 33$ & 283 & 369 & 104 & $3 I$ & 743 & 201 & 60 & 0.622 & 0.176 & $1 \cdot 015$ \\
\hline 8 & 5.50 & 3.50 & 363 & 394 & 143 & 41 & 543 & I97 & 56 & 0.600 & 0.218 & $1 \cdot 013$ \\
\hline 9 & 10.25 & $4 \cdot 58$ & 201 & 593 & II9 & 26 & 655 & 132 & 29 & 0.943 & 0.190 & $I \cdot 02 I$ \\
\hline IO & I 1.30 & $\mathrm{I} \cdot 08$ & 276 & 117 & 32 & 28 & 178 & 49 & 45 & 0.285 & 0.079 & $I \cdot 006$ \\
\hline II & 4.30 a.m. & $5 \cdot 00$ & 344 & 207 & 71 & 13 & 541 & I86 & 34 & 0.789 & 0.275 & I.013 \\
\hline 12 & 12 noon & $7 \cdot 50$ & 363 & 333 & I2I & 16 & 591 & 215 & 29 & 0.745 & 0.270 & I.OII \\
\hline 13 & 2.30 p.m. & 2.50 & 258 & 266 & 67 & 27 & 474 & 122 & 49 & 0.706 & 0.182 & $I \cdot 012$ \\
\hline 14 & 5.50 & $3 \cdot 33$ & 175 & 371 & 65 & 17 & 609 & 107 & 28 & 0.956 & 0.167 & $1 \cdot 018$ \\
\hline 15 & 9.50 & 4.00 & 276 & 451 & 125 & $3 I$ & 566 & 156 & 39 & 0.887 & 0.245 & I.01 8 \\
\hline 16 & 5.00 a.m. & $7 \cdot 16$ & 538 & 291 & 157 & 22 & 592 & 318 & 44 & I.094 & 0.588 & $1 \cdot 016$ \\
\hline 17 & 9.30 & 4.50 & 44 & 402 & 17 & 4 & $I, 482$ & 65 & I4 & $2 \cdot 360$ & 0.104 & $I \cdot 021$ \\
\hline Total & & $71 \cdot 67$ & 4,883 & & 1,700 & & & 2,754 & & & 3.990 & \\
\hline ‘Mean' & & & & 350 & & $22 \cdot 6$ & 563 & & $35 \cdot 9$ & 0.8171 & & \\
\hline
\end{tabular}


TABLE AV

Observed Results from Spot Urine Specimens: Patient P2

\begin{tabular}{|c|c|c|c|c|c|c|c|c|c|c|c|c|}
\hline \multirow{2}{*}{$\begin{array}{l}\text { Speci- } \\
\text { men }\end{array}$} & \multirow{2}{*}{$\begin{array}{l}\text { Time of } \\
\text { Collection }\end{array}$} & \multirow{2}{*}{$\begin{array}{l}\text { Hours } \\
\text { Between } \\
\text { Voidings }\end{array}$} & \multirow{2}{*}{$\begin{array}{l}\text { Volume } \\
(m l .)\end{array}$} & \multicolumn{3}{|c|}{ Lead ( $\mu g)}$. & \multicolumn{3}{|c|}{ Coproporphyrin ( $\mu g)}$. & \multicolumn{2}{|c|}{ Creatinine $(g)}$. & \multirow{2}{*}{$\begin{array}{l}\text { Specific } \\
\text { Gravity }\end{array}$} \\
\hline & & & & Litre & $\begin{array}{l}\text { Speci- } \\
\text { men }\end{array}$ & Hour & Litre & $\begin{array}{l}\text { Speci- } \\
\text { men }\end{array}$ & Hour & Litre & $\begin{array}{l}\text { Speci- } \\
\text { men }\end{array}$ & \\
\hline $\mathbf{I}$ & 9.00 a.m. & 一 & 265 & 165 & 44 & - & 45 & 12 & - & 0.806 & 0.214 & I.0I3 \\
\hline 2 & 12 noon & 3.00 & 345 & 88 & 30 & 10.00 & 72 & 25 & $8 \cdot 33$ & 0.303 & 0.105 & $I \cdot 004$ \\
\hline 3 & 4.00 p.m. & $4 \cdot 00$ & 415 & 37 & 15 & 3.75 & 144 & 60 & 15.00 & 0.542 & 0.225 & $1 \cdot 015$ \\
\hline 4 & 8.45 & $4 \cdot 75$ & 390 & 150 & 59 & $12 \cdot 40$ & 88 & 34 & $7 \cdot 16$ & 0.797 & 0.311 & $1 \cdot 016$ \\
\hline 5 & 11.30 & $2 \cdot 75$ & 280 & 98 & 27 & 9.80 & 85 & 24 & $8 \cdot 73$ & 0.844 & 0.235 & $1 \cdot 019$ \\
\hline 6 & 5.00 a.m. & 5.50 & 450 & 98 & 44 & $8 \cdot 00$ & 107 & 48 & $8 \cdot 73$ & $1 \cdot 033$ & 0.465 & $1 \cdot 020$ \\
\hline 7 & I 1.30 & 6.50 & 485 & 100 & 49 & $7 \cdot 50$ & 44 & 21 & 3.23 & 0.371 & 0.180 & $1 \cdot 008$ \\
\hline 8 & 4.00 p.m. & 4.50 & 335 & 106 & 36 & $8 \cdot 00$ & 57 & 17 & $3 \cdot 78$ & 0.585 & 0.200 & I·OII \\
\hline 9 & 8.00 & 4.00 & 585 & 52 & 30 & $7 \cdot 50$ & 47 & 28 & 7.00 & $1 \cdot 014$ & 0.593 & $1 \cdot 018$ \\
\hline 10 & 9.00 a.m. & 13.00 & 430 & 88 & 38 & 3.50 & 18 & 8 & 0.73 & 0.255 & 0.120 & $1 \cdot 007$ \\
\hline II & 1.00 p.m. & $4 \cdot 00$ & 405 & 115 & 47 & $11 \cdot 80$ & 78 & 32 & 8.00 & I.019 & 0.413 & $I \cdot 020$ \\
\hline 12 & 6.00 & 5.00 & 475 & 87 & $4 I$ & $8 \cdot 20$ & 3 & 2 & 0.40 & 0.753 & 0.358 & $1 \cdot 017$ \\
\hline 13 & I1.30 & 5.50 & 325 & 53 & 17 & $3 \cdot 10$ & 6 & 2 & 3.60 & 0.533 & 0.173 & I.OII \\
\hline 14 & 12 noon & $12 \cdot 50$ & 370 & 45 & 17 & $2 \cdot 60$ & 42 & 16 & $1 \cdot 28$ & 0.258 & 0.095 & I.006 \\
\hline 15 & 2.25 p.m. & 2.42 & 375 & 75 & 28 & $11 \cdot 60$ & 47 & 18 & $7 \cdot 44$ & 0.346 & 0.130 & $1 \cdot 004$ \\
\hline 16 & 7.00 & $4 \cdot 58$ & 380 & 76 & 29 & 6.40 & 92 & 35 & $7 \cdot 64$ & 0.700 & 0.266 & $1 \cdot 016$ \\
\hline 17 & 5.30 a.m. & 10.50 & 570 & 80 & 46 & $4 \cdot 40$ & 83 & 47 & 4.48 & 0.775 & 0.442 & $1 \cdot 018$ \\
\hline Total & & $92 \cdot 50$ & 6,880 & & 597 & & & 429 & & & 4.525 & \\
\hline 'Mean' & & & & $86 \cdot 77$ & & $6 \cdot 45$ & $62 \cdot 4$ & & $5 \cdot 34$ & 0.658 & & \\
\hline
\end{tabular}

TABLE AVI

Observed Results from Spot Urine Specimens: Patient U

\begin{tabular}{|c|c|c|c|c|c|c|c|c|c|c|c|c|}
\hline \multirow{2}{*}{$\begin{array}{l}\text { Speci- } \\
\text { men }\end{array}$} & \multirow{2}{*}{$\begin{array}{l}\text { Time of } \\
\text { Collection }\end{array}$} & \multirow{2}{*}{$\begin{array}{l}\text { Hours } \\
\text { Between } \\
\text { Voidings }\end{array}$} & \multirow{2}{*}{$\begin{array}{l}\text { Volume } \\
(m l .)\end{array}$} & \multicolumn{3}{|c|}{ Lead $(\mu g)}$. & \multicolumn{3}{|c|}{ Coproporphyrin ( $\mu g)}$. & \multicolumn{2}{|c|}{ Creatinine (g.) } & \multirow{2}{*}{$\begin{array}{l}\text { Specific } \\
\text { Gravity }\end{array}$} \\
\hline & & & & Litre & $\begin{array}{l}\text { Speci- } \\
\text { men }\end{array}$ & Hour & Litre & $\begin{array}{l}\text { Speci- } \\
\text { men }\end{array}$ & Hour & Litre & $\begin{array}{l}\text { Speci- } \\
\text { men }\end{array}$ & \\
\hline $\mathbf{I}$ & 3.40 p.m. & 一 & 310 & $5 I$ & 16 & - & 95 & 30 & 一 & 0.679 & $0.21 I$ & $1 \cdot 008$ \\
\hline 2 & 9.30 & $5 \cdot 83$ & 320 & 84 & 27 & $4 \cdot 63$ & 74 & 25 & $4 \cdot 29$ & 0.766 & 0.245 & I.014 \\
\hline 3 & I2.20 a.m. & $2 \cdot 83$ & 340 & 50 & I7 & $6 \cdot 00$ & 98 & 35 & $12 \cdot 37$ & 0.434 & 0.148 & $1 \cdot 012$ \\
\hline 4 & 4.40 & $4 \cdot 33$ & 420 & 35 & 15 & $3 \cdot 46$ & 65 & 28 & $6 \cdot 47$ & 0.587 & 0.247 & I.oro \\
\hline 5 & 6.25 & $1 \cdot 75$ & 188 & $4 I$ & 8 & $4 \cdot 57$ & 121 & 23 & $13 \cdot 14$ & 0.744 & 0.140 & $1 \cdot 012$ \\
\hline 6 & 9.25 & $3 \cdot 00$ & 215 & 25 & 5 & $\mathrm{r} \cdot 67$ & 124 & 28 & 9.33 & $I \cdot 031$ & 0.220 & $1 \cdot 009$ \\
\hline 7 & I1.20 & $1 \cdot 92$ & 229 & 38 & 9 & 4.69 & 105 & 25 & 13.02 & 0.628 & 0.144 & $1 \cdot 007$ \\
\hline 8 & 3.45 p.m. & $4 \cdot 43$ & $45^{\circ}$ & 48 & 22 & 4.63 & 205 & 93 & 19.58 & 0.587 & 0.265 & $1 \cdot 008$ \\
\hline 9 & 5.35 & 1.83 & 340 & 50 & 17 & $9 \cdot 29$ & 127 & 43 & 23.50 & 0.392 & 0.133 & $1 \cdot 006$ \\
\hline 10 & 8.00 & $2 \cdot 42$ & 320 & 30 & Io & $4 \cdot 13$ & 118 & 38 & $15 \cdot 70$ & 0.514 & 0.164 & $1 \cdot 005$ \\
\hline II & II.15 & 3.25 & 355 & 45 & 16 & 4.92 & 123 & 44 & 13.54 & 0.448 & 0.159 & $1 \cdot 006$ \\
\hline 12 & 3.45 a.m. & 4.50 & 410 & 27 & II & $2 \cdot 44$ & III & 46 & 10.22 & - & - & - \\
\hline 13 & 5.45 & 2.00 & 345 & $5 I$ & 18 & $9 \cdot 00$ & 149 & 52 & $26 \cdot 00$ & 0.539 & 0.186 & $1 \cdot 006$ \\
\hline 14 & 10.05 & $4 \cdot 33$ & 195 & 76 & 15 & $3 \cdot 46$ & 540 & 105 & $24 \cdot 25$ & $I \cdot 471$ & 0.287 & $1 \cdot 012$ \\
\hline 15 & 12.20 p.m. & $2 \cdot 25$ & 260 & 40 & 10 & $4 \cdot 44$ & 199 & 52 & $23 \cdot 11$ & 0.420 & 0.109 & $1 \cdot 009$ \\
\hline 16 & 2.50 & $2 \cdot 50$ & 215 & 30 & 6 & $2 \cdot 40$ & 122 & 26 & 10.40 & 0.425 & 0.091 & $1 \cdot 007$ \\
\hline 17 & 4.55 & 2.08 & 176 & 55 & 14 & $6 \cdot 73$ & 173 & 31 & $14 \cdot 90$ & 0.643 & 0.113 & $1 \cdot 012$ \\
\hline 18 & 7.10 & $2 \cdot 25$ & 240 & 35 & 14 & $6 \cdot 22$ & 172 & 41 & $18 \cdot 22$ & 0.589 & 0.141 & I.010 \\
\hline 19 & I0.10 & 3.00 & 402 & 43 & 14 & $4 \cdot 66$ & 137 & 55 & $18 \cdot 33$ & 0.715 & 0.287 & I.010 \\
\hline 20 & 5.20 a.m. & $7 \cdot 17$ & 320 & 50 & II & I.53 & 171 & 55 & 7.67 & 0.790 & 0.253 & I.010 \\
\hline 21 & 7.15 & $1 \cdot 83$ & 205 & 31 & 7 & 3.83 & 226 & 47 & $25 \cdot 68$ & 0.776 & 0.159 & $1 \cdot 008$ \\
\hline $\begin{array}{l}\text { Total } \\
\text { 'Mean' }\end{array}$ & & 63.50 & 6,255 & & 282 & & & 922 & & & $3 \cdot 702$ & \\
\hline 'Mean' & & & & $45 \cdot I$ & & $4 \cdot 44$ & $147 \cdot 4$ & & 14.03 & 0.633 & & \\
\hline
\end{tabular}


TABLE AVII

Proportions of 'Mean' Excretion: Patient C

\begin{tabular}{|c|c|c|c|c|c|c|c|c|c|c|c|}
\hline \multirow{3}{*}{$\begin{array}{l}\text { Speci- } \\
\text { men }\end{array}$} & \multirow[t]{3}{*}{ Time } & \multicolumn{4}{|l|}{ Lead } & \multicolumn{4}{|c|}{ Coproporphyrin } & \multirow{3}{*}{$\begin{array}{l}\text { Creatinine } \\
(\% \text { con- } \\
\text { centra- } \\
\left.\text { tion }^{3}\right)\end{array}$} & \multirow{3}{*}{$\begin{array}{l}\text { Specific } \\
\text { Gravity }\end{array}$} \\
\hline & & \multirow{2}{*}{$\begin{array}{l}\% \text { Con- } \\
\text { centra- } \\
\text { tion }^{1}\end{array}$} & \multirow[t]{2}{*}{$\begin{array}{l}\% \text { Ratel } \\
\text { hour }^{2}\end{array}$} & \multicolumn{2}{|c|}{$\begin{array}{l}\text { Concentration } \\
\text { adjusted to }\end{array}$} & \multirow{2}{*}{$\begin{array}{l}\% \text { Con- } \\
\text { centra- } \\
\text { tion }^{1} \\
e^{\text {nat }}\end{array}$} & \multirow[t]{2}{*}{$\begin{array}{l}\% \text { Ratel } \\
\text { hour }^{2}\end{array}$} & \multicolumn{2}{|c|}{$\begin{array}{l}\text { Concentration } \\
\text { adjusted to }\end{array}$} & & \\
\hline & & & & $\begin{array}{l}\text { Specific } \\
\text { Gravity }\end{array}$ & Creatinine & & & $\begin{array}{l}\text { Specific } \\
\text { Gravity }\end{array}$ & Creatinine & & \\
\hline $\mathbf{I}$ & I.30 p.m. & 66 & - & 198 & I35 & 43 & - & 131 & 89 & 49 & $1 \cdot 005$ \\
\hline 2 & 5.00 & 98 & 204 & 164 & 121 & 78 & 117 & 130 & 96 & 80 & $1 \cdot 009$ \\
\hline 3 & 9.15 & I95 & 164 & 2 II & 145 & 116 & 9I & 125 & 85 & 135 & $1 \cdot 014$ \\
\hline 4 & 10.15 & 88 & 107 & 102 & 72 & I2I & 32 & 142 & 100 & 121 & $1 \cdot 013$ \\
\hline 5 & 6.15 a.m. & 76 & 27 & 89 & 38 & 237 & 85 & 276 & 119 & 199 & $1 \cdot 013$ \\
\hline 6 & II.I5 & 60 & 70 & 103 & 100 & 72 & 78 & 155 & 119 & 60 & I. .007 \\
\hline 7 & I.30 p.m. & I4I & 170 & 179 & 163 & 142 & 163 & 179 & 163 & 86 & $1 \cdot 012$ \\
\hline 8 & 5.45 & 129 & 159 & 217 & 145 & 126 & 146 & 212 & 142 & 88 & I.009 \\
\hline 9 & 10.00 & 137 & 159 & 173 & 140 & 106 & II6 & 133 & 107 & 98 & $1 \cdot 012$ \\
\hline IO & 6.45 a.m. & 151 & 52 & 143 & 45 & 240 & 64 & 227 & 72 & 335 & $1 \cdot 016$ \\
\hline I I & 9.00 & 40 & 60 & I52 & 88 & 76 & IOI & 288 & 167 & 46 & $I \cdot 004$ \\
\hline 12 & 10.45 & 68 & 169 & I7I & 85 & 50 & 124 & I3I & 65 & 79 & I.006 \\
\hline 13 & I.00 p.m. & 96 & 143 & 180 & 132 & $8 I$ & 120 & 152 & 112 & 72 & $I \cdot 008$ \\
\hline \multirow{2}{*}{\multicolumn{2}{|c|}{$\begin{array}{l}\text { Average } \\
\mathrm{n}\end{array}$}} & 103.5 & $123 \cdot 7$ & $160 \cdot 2$ & $108 \cdot 4$ & II 4.5 & $103 \cdot 1$ & $175 \cdot 5$ & 110.5 & & \\
\hline & & 13 & 12 & 13 & 13 & 13 & 12 & 13 & 13 & & \\
\hline
\end{tabular}

TABLE AVIII

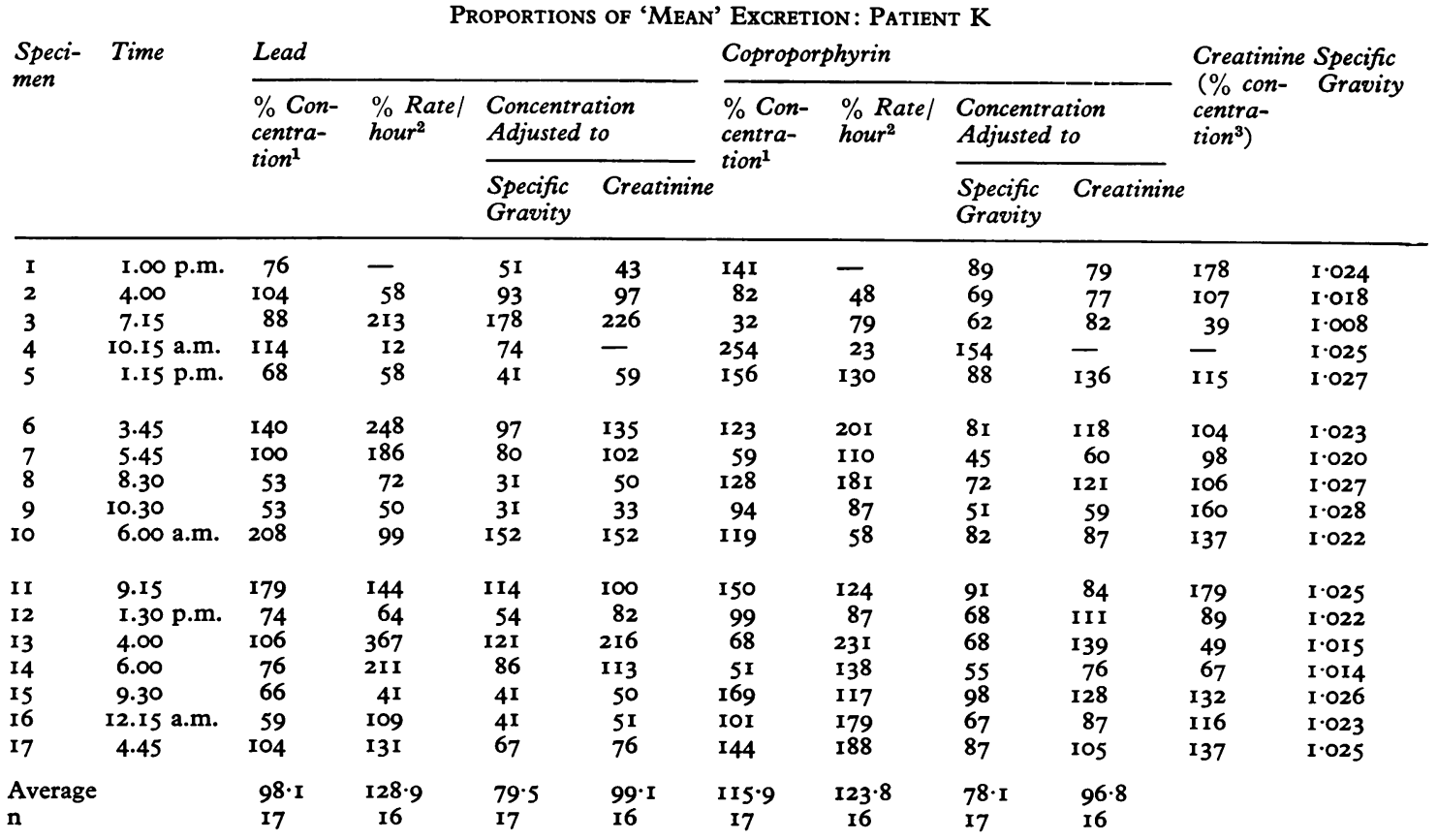

${ }^{1}$ Working units $\mu \mathrm{g} . /$ litre; weighted 'mean' concentration $=100 \%$.

${ }^{2}$ Working units $\mu$ g./hour; weighted 'mean' rate $=100 \%$.

${ }^{3}$ Working units g./litre; weighted 'mean' concentration $=100 \%$. 
TABLE AIX

Proportions of 'Mean' Excretion: Patient N

\begin{tabular}{|c|c|c|c|c|c|c|c|c|c|c|c|}
\hline \multirow{3}{*}{$\begin{array}{l}\text { Speci- } \\
\text { men }\end{array}$} & \multirow[t]{3}{*}{ Time } & \multicolumn{4}{|l|}{ Lead } & \multicolumn{4}{|c|}{ Coproporphyrin } & \multirow{3}{*}{$\begin{array}{l}\text { Creatinine } \\
(\% \text { con- } \\
\text { centra- } \\
\left.\text { tion }^{3}\right)\end{array}$} & \multirow{3}{*}{$\begin{array}{l}\text { Specific } \\
\text { Gravity }\end{array}$} \\
\hline & & \multirow{2}{*}{$\begin{array}{l}\% \text { Con- } \\
\text { centra- } \\
\text { tion }^{1}\end{array}$} & \multirow[t]{2}{*}{$\begin{array}{l}\% \text { Ratel } \\
\text { hour }\end{array}$} & \multicolumn{2}{|c|}{$\begin{array}{l}\text { Concentration } \\
\text { adjusted to }\end{array}$} & \multirow{2}{*}{$\begin{array}{l}\% \text { Con- } \\
\text { centra- } \\
\text { tion }^{1}\end{array}$} & \multirow[t]{2}{*}{$\begin{array}{l}\% \text { Ratel } \\
\text { hour }{ }^{2}\end{array}$} & \multicolumn{2}{|c|}{$\begin{array}{l}\text { Concentration } \\
\text { adjusted to }\end{array}$} & & \\
\hline & & & & $\begin{array}{l}\text { Specific } \\
\text { Gravity }\end{array}$ & Creatinine & & & $\begin{array}{l}\text { Specific } \\
\text { Gravity }\end{array}$ & Creatinine & & \\
\hline $\mathbf{I}$ & 2.00 p.m. & 165 & - & 94 & II5 & 220 & - & 126 & I54 & 143 & $1 \cdot 028$ \\
\hline 2 & 7.15 & 204 & 153 & 142 & 224 & I54 & 116 & 107 & 169 & 91 & $1 \cdot 023$ \\
\hline 3 & 10.30 & 136 & 141 & II5 & 94 & 95 & 99 & 80 & 66 & 144 & I.019 \\
\hline 4 & 6.00 a.m. & 83 & 46 & 74 & - & 130 & 72 & 116 & - & - & $1 \cdot 018$ \\
\hline 5 & 8.30 & 100 & 59 & 80 & 74 & I77 & IOI & 142 & I3I & 135 & $1 \cdot 020$ \\
\hline 6 & 10.15 & 78 & 135 & 139 & - & 50 & 108 & 89 & - & - & $1 \cdot 009$ \\
\hline 7 & I.00 p.m. & 63 & 144 & 112 & - & 71 & 162 & 126 & - & - & $1 \cdot 009$ \\
\hline 8 & 3.45 & 33 & 88 & 75 & 97 & 61 & 166 & 139 & I79 & 34 & 1.007 \\
\hline 9 & $7 \cdot 30$ & 92 & 113 & 123 & 180 & 84 & 138 & 112 & 165 & 51 & $1 \cdot 012$ \\
\hline 10 & 10.45 & 149 & 123 & 119 & I94 & 143 & I 18 & 114 & I86 & 77 & $1 \cdot 020$ \\
\hline II & 5.45 a.m. & 173 & 65 & - & 173 & 160 & 60 & - & 160 & 100 & - \\
\hline 12 & 9.30 & 170 & 75 & 113 & 405 & 273 & 123 & 182 & 650 & 42 & $I \cdot 024$ \\
\hline 13 & II.15 & 59 & 100 & 135 & 58 & 67 & III & 153 & 66 & 102 & $1 \cdot 007$ \\
\hline 14 & 1.00 p.m. & I54 & 154 & 164 & 214 & 195 & I99 & 208 & 270 & 72 & 1.015 \\
\hline 15 & 4.00 & 76 & 197 & - & 44 & 59 & 155 & - & 34 & 175 & - \\
\hline 16 & 6.30 & I6I & 148 & 129 & 108 & 135 & 124 & 108 & 9I & 149 & $1 \cdot 020$ \\
\hline 17 & 9.00 & 215 & 162 & 156 & I4I & 150 & II 4 & 109 & 98 & 153 & $1 \cdot 022$ \\
\hline 18 & 10.45 & 169 & 100 & - & 393 & 190 & I II & - & 441 & 43 & - \\
\hline 19 & 4.30 a.m. & 65 & 89 & 87 & 65 & 53 & 72 & 71 & 53 & 100 & $1 \cdot 012$ \\
\hline 20 & I0.15 & 71 & 42 & II4 & 68 & 91 & 53 & 146 & 88 & 104 & I.OIO \\
\hline 21 & 12.45 p.m. & 130 & 100 & 122 & 169 & 96 & 73 & 90 & 125 & 77 & $1 \cdot 017$ \\
\hline $\begin{array}{l}\text { Average } \\
\text { n }\end{array}$ & & $\begin{array}{l}12 I \cdot 2 \\
2 I\end{array}$ & $\begin{array}{l}\text { III } \cdot 7 \\
20\end{array}$ & $\begin{array}{c}\text { I16.3 } \\
18\end{array}$ & $\begin{array}{c}156.4 \\
18\end{array}$ & $\begin{array}{c}126 \cdot 4 \\
21\end{array}$ & $\begin{array}{c}113.8 \\
20\end{array}$ & $\begin{array}{c}123 \cdot 2 \\
18\end{array}$ & $\begin{array}{c}173 \cdot 7 \\
18\end{array}$ & & \\
\hline
\end{tabular}

TABLE AX

Proportions of 'Mean' Excretion: Patient P

\begin{tabular}{|c|c|c|c|c|c|c|c|c|c|c|c|}
\hline \multirow{3}{*}{$\begin{array}{l}\text { Speci- } \\
\text { men }\end{array}$} & \multirow[t]{3}{*}{ Time } & \multicolumn{4}{|l|}{ Lead } & \multicolumn{4}{|c|}{ Coproporphyrin } & \multirow{3}{*}{$\begin{array}{l}\text { Creatinine } \\
\text { (\% con- } \\
\text { centra- } \\
\left.\text { tion }^{3}\right)\end{array}$} & \multirow{3}{*}{$\begin{array}{l}\text { Specific } \\
\text { Gravity }\end{array}$} \\
\hline & & \multirow{2}{*}{$\begin{array}{l}\% \text { Con- } \\
\text { centra- } \\
\text { tion }^{1}\end{array}$} & \multirow[t]{2}{*}{$\begin{array}{l}\% \text { Ratel } \\
\text { hour }^{2}\end{array}$} & \multicolumn{2}{|c|}{$\begin{array}{l}\text { Concentration } \\
\text { adjusted to }\end{array}$} & \multirow{2}{*}{$\begin{array}{l}\% \text { Con- } \\
\text { centra- } \\
\text { tion } 1\end{array}$} & \multirow[t]{2}{*}{$\begin{array}{l}\% \text { Ratel } \\
\text { hour }^{2}\end{array}$} & \multicolumn{2}{|c|}{$\begin{array}{l}\text { Concentration } \\
\text { adjusted to }\end{array}$} & & \\
\hline & & & & $\begin{array}{l}\text { Specific } \\
\text { Gravity }\end{array}$ & Creatinine & & & $\begin{array}{l}\text { Specific } \\
\text { Gravity }\end{array}$ & Creatinine & & \\
\hline I. & 9.50 a.m. & 100 & - & II4 & IOI & 92 & - & 105 & 93 & 99 & I.014 \\
\hline 2 & I.00 p.m. & I3I & 239 & I9I & 252 & 68 & 126 & 99 & 131 & 52 & I.OII \\
\hline 3 & 6.30 & 134 & 99 & 113 & 122 & 94 & 67 & 79 & 85 & I 10 & I.019 \\
\hline 4 & 9.15 & 142 & 189 & 120 & 146 & 108 & 142 & 91 & I I I & 97 & $1 \cdot 019$ \\
\hline 5 & 3.15 a.m. & 68 & 59 & 83 & $5 I$ & III & 92 & 137 & 83 & 134 & $1 \cdot 013$ \\
\hline 6 & 11.00 & 93 & 45 & II 4 & 80 & 133 & 67 & I64 & 115 & II6 & $1 \cdot 013$ \\
\hline 7 & 2.20 p.m. & ros & 140 & 112 & 138 & 132 & 167 & $14 \mathrm{I}$ & 173 & 76 & 1.015 \\
\hline 8 & 5.50 & 113 & 185 & 139 & 155 & 96 & 156 & II8 & 132 & 73 & $1 \cdot 013$ \\
\hline 9 & 10.25 & 169 & 117 & 129 & 150 & 116 & 81 & 89 & 113 & II3 & $I \cdot 02 I$ \\
\hline 10 & 11.30 & 33 & 126 & 89 & 94 & 32 & 126 & 84 & 91 & 35 & $1 \cdot 006$ \\
\hline II & 4.30 a.m. & 59 & 59 & 73 & 60 & 96 & 95 & II 8 & 98 & 98 & $1 \cdot 013$ \\
\hline 12 & 12 noon & 95 & 72 & 139 & 104 & 105 & 81 & 153 & 115 & 91 & I.OII \\
\hline 13 & 2.30 p.m. & 76 & 121 & IOI & 88 & 84 & 137 & 112 & 98 & 86 & $1 \cdot 012$ \\
\hline 14 & 5.50 & 106 & 77 & 94 & $9 I$ & 108 & 78 & 96 & 92 & 117 & $1 \cdot 018$ \\
\hline 15 & 9.50 & 129 & 140 & 115 & 118 & IOI & 109 & 89 & 93 & 109 & $1 \cdot 018$ \\
\hline 16 & 5.00 a.m. & 83 & 99 & 83 & 62 & 105 & 123 & 105 & 78 & 134 & $1 \cdot 016$ \\
\hline 17 & 9.30 & 115 & 18 & 87 & 40 & 263 & 39 & 201 & 9I & 289 & $I \cdot 02 I$ \\
\hline $\begin{array}{l}\text { Average } \\
\mathrm{n}\end{array}$ & & $\begin{array}{c}103 \cdot 0 \\
17\end{array}$ & $\begin{array}{l}111 \cdot 6 \\
16\end{array}$ & $\begin{array}{l}\text { III } 15 \\
17\end{array}$ & $\begin{array}{l}108 \cdot 9 \\
17\end{array}$ & $\begin{array}{c}108 \cdot 5 \\
17\end{array}$ & $\begin{array}{c}105 \cdot 4 \\
16\end{array}$ & $\begin{array}{l}116 \cdot 5 \\
17\end{array}$ & $\begin{array}{c}105 \cdot 4 \\
17\end{array}$ & & \\
\hline
\end{tabular}

Creatinine Specific 
TABLE AXI

Proportions of 'Mean' Excretion: Patient P2

Speci- Time men
Lead

$\%$ Con- \% Ratel Concentration centra- hour ${ }^{2}$ adjusted to tion ${ }^{1}$
Coproporphyrin

Concentration centra- hour ${ }^{2}$ adjusted to tion $^{1}$
Creatinine Specific

(\% con- Gravity

centra-

tion $^{3}$ )

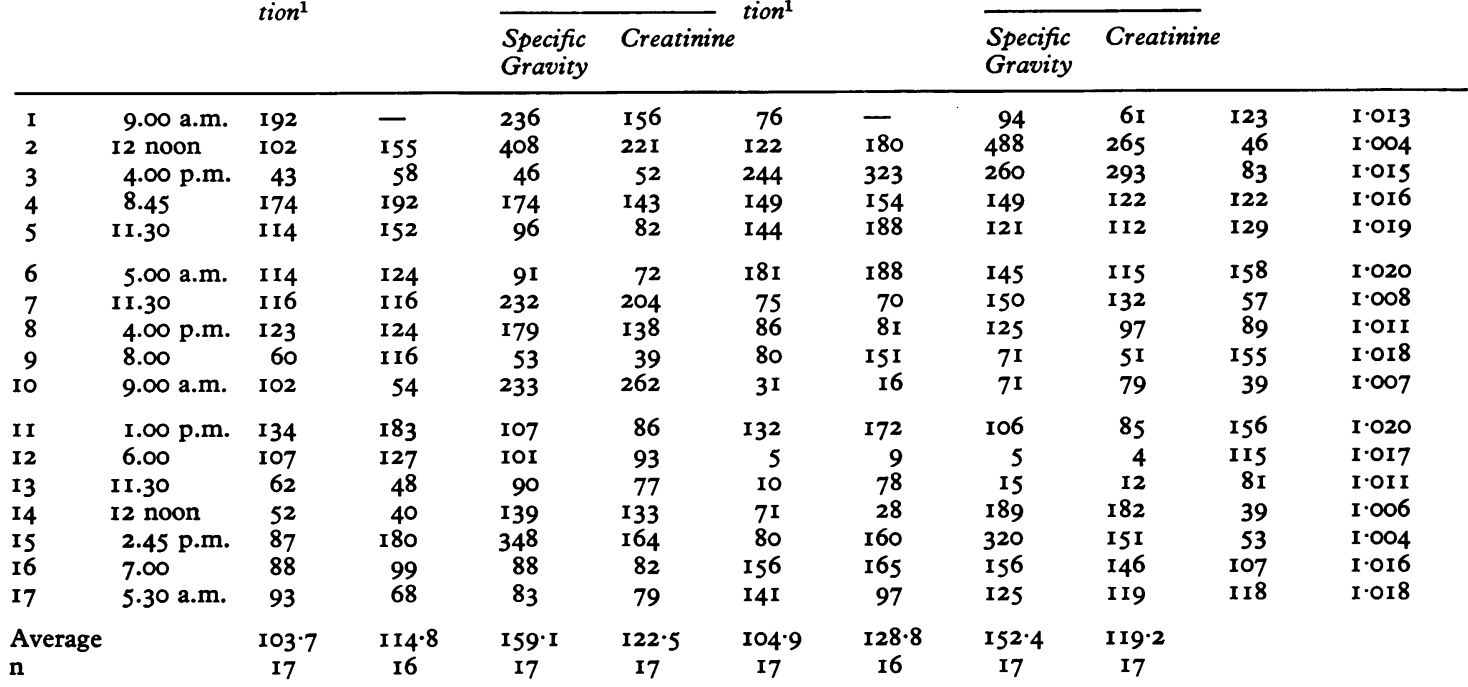

TABLE AXII

Proportions of 'Mean' Excretion: Patient U

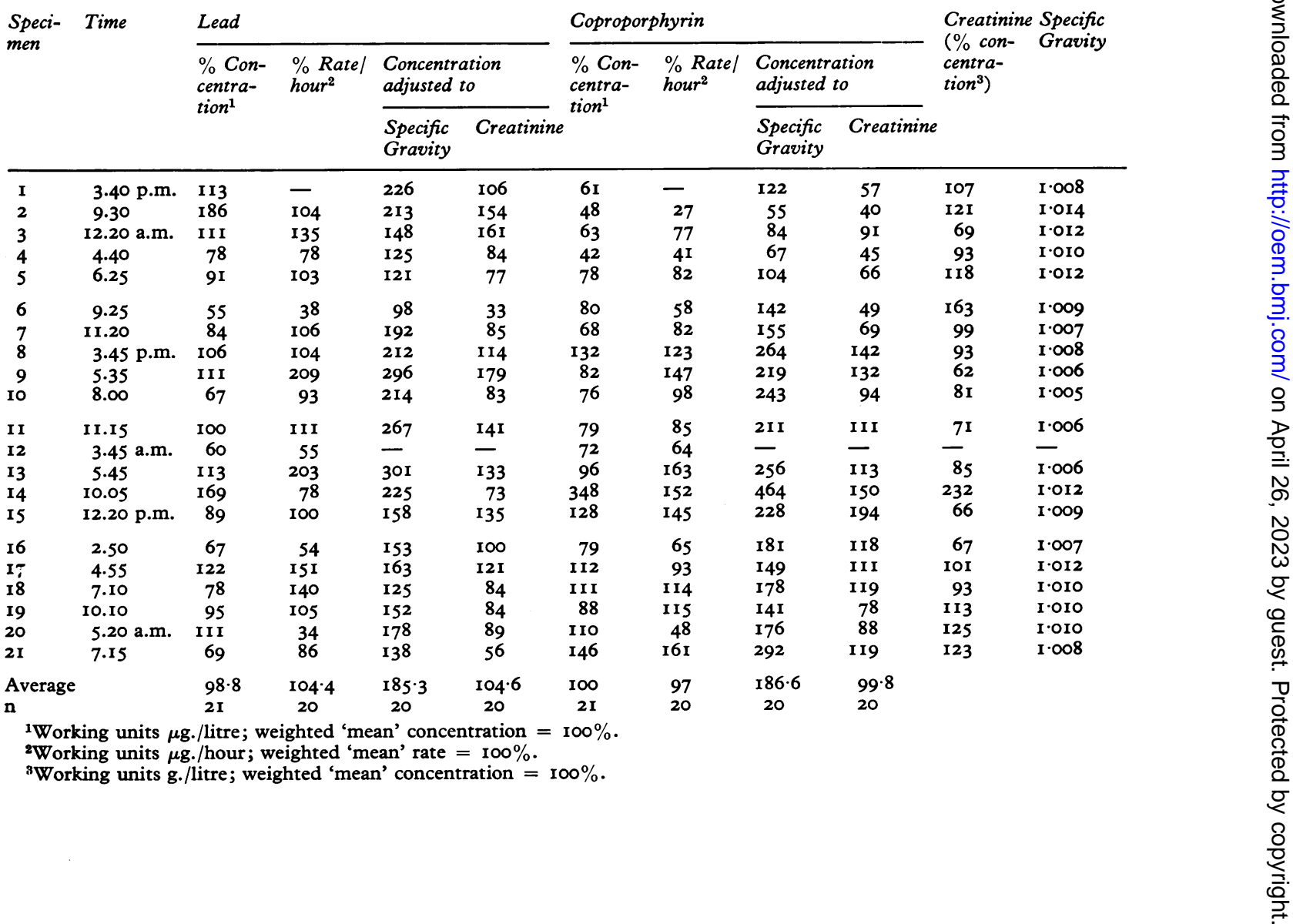

